\title{
Impact of Financial Market Uncertainty on Market Returns: A Global Analysis
}

\author{
Maryam Abid (Corresponding Author) \\ Research Scholar, Karachi University Business School, University Of Karachi, Pakistan \\ E-mail: maryamabid6@yahoo.com
}

\begin{abstract}
Danish Ahmed Siddique
Associate Professor, Karachi University Business School, University Of Karachi, Pakistan

Email: daanish79@hotmail.com
\end{abstract}

Received: July 2, 2020 Accepted: July 18, 2020 Published: July 27, 2020

doi:10.5296/ber.v10i3.17276 URL: https://doi.org/10.5296/ber.v10i3.17276

\begin{abstract}
This paper examines the effect of financial market uncertainty on market returns of different countries of the world. The effect of other macroeconomic like Consumer Price Index (CPI), Real Interest Rates (R.IR), Market Capitalization (MCAP), and Gross Domestic Product per capita growth (GDPPCG).For analyzing this relationship, around 40 countries data including developed and developing countries, over the period of 10 years from 2009-2018. For analysis, Panel Least Square (PLS) was used. Fixed Effect Model (FEM) is used to check the overall strength of the model. Group correlation was also performed on overall variables to check the causal relationship between all the variables and individual regression tests are also conducted country wise to explore that how much this model is applicable, descriptive analysis for market return and uncertainty to check the moments of these variables. The overall results it is concluded that market returns are affected by the financial markets uncertainty in the long run and it is a significant variable in explaining market returns while overall test results proved a positive relationship with market returns but individual testing of this model on each country shows, more than half countries in the study have a negative relationship of financial market uncertainty with market returns. Along this, other macro-economic variables impact is also measured over market returns of the world which shows all variables Consumer Price Index, Real Interest Rates and Market Capitalization except Gross Domestic Product per capita growth have a negative relationship with the Equity Market returns.
\end{abstract}


Keywords: Market Uncertainty, Market Returns, Macro-economic variables, Consumer Price Index, Market Capitalization, Real Interest Rates and Cross-sectional Absolute Standard Deviation

\section{Introduction}

\subsection{Background of the Study}

Market analyst Frank Knight in1921 gave the concept of Risk and Uncertainty and both identity as the equivalent idea which is randomness so the risk is a randomness of events which have quantifiable probabilities. All these probabilities might be accomplished either by induction (utilizing theoretical models) or deduction (utilizing the observed recurrence of events). Like we can check the probabilities by rolling a dice similarly in economics we can check the probabilities of stock market return by using theoretical models based on investor behaviors.

So, measurable uncertainty is apprehensive, many concepts have been established to calculate the uncertainty. For example, Chulia et al. (2017) gave a daily index of time-varying stock to measure equity market uncertainty. This model contributes to a daily measurement of uncertainty values because it means the market can be monitored in real-time for checking uncertainty effects. Fair (2002), Bomfim (2003) and Chulia Martens (2010) emphasize on the estimation of impacts take out from event studies is much more precise and less strident as the frequency of the data increases. Jussi Nikkinen (2004) used the CBOE VIX as a proxy for the expected volatility of the U.S equity market to calculate market uncertainty. Engle (2002) and Kang et al. (2014) also used realized volatilities, conditional volatility measured from a stochastic volatility model, and implied volatility deduced from option prices to measure uncertainty.

\subsection{Problem Statement}

This is a major problem and irrational view to follow up with other investors, in which the psychology of an investor is fully controlled by other investor's actions and they disregarded their own beliefs and perceptions just to follow other investors blindly (Devenow and Welch, 1996).

Scharfstein and Stein (1990); Rajan (1994) discussed the rational concept which focused on the major reasons at which investors followed the doings of the others by completely neglecting personal information and criteria to hold their reputational capital which is invested in the market. Similarly, this behavior is called an informational cascade (Bikhchandani et al., 1992; Welch, 1992).

Herd behavior is falls in the example of an irrational view and this concept is more important while the financial market is majorly controlled by a large number of institutional investors. These investors are appraised according to the performance of peer groups so they should be careful while making choices on their own priors and neglecting the suggestions of related managers. On the other side, institutional investors focus majorly on the suggestion of other professionals in the event of purchasing and vending for more uncertain stock investments. 
Irrationality in the stock market triggered by many reasons in which uncertainty avoidance behavior of investors is the major reason. Sometimes Unreasonable analyst's anticipations as a result of more uncertainty in the stock market (George Bulkley and Richard D. F. Harris, 1997). Uncertain behavior of the investors based on the macro events and floating information in the market caused irrational changes in the stock markets which ultimately results in stock returns volatility. This is the major reason for uncertainty in the stock market which must be explored to reduce the volatility fluctuations in the stock market and ultimately guiding the investors that how to keep the focus on their investment without making any uncertain situation in the market.

\subsection{Gap Analysis}

US Equity market participants' behavior examined by using the cross-sectional standard deviation of returns (CSSD) for calculating the mean proximity of separate asset returns to the realized market means, so based on this researcher created an assessment of herd behavior. In short, observed the behavior of CSSD under different market conditions. However, no such study was conducted on a developing countries like Pakistan.

On a more recent note, Gupta et al. (2019) provided a brief past view over the establishment of daily frequencies shocks over the bull and bear moments of returns of the stock market in the US. Sarwar \& Khan (2016) explored the concept of Uncertainty over stock market returns, in this paper, they just covered the US stock Market Uncertainty not overall or individual Financial Market Uncertainties of countries over the Latin America or aggregate Emerging Markets. However, since financial markets are not that developed in developing countries, VIX options are mostly unavailable for a large cross section, hence to conduct a cross-country study involving different countries, we have to rely on Christie and Huang (1995) and Chang et al. (2000) methodology. Many country-specific studies were conducted in the past mostly involving developed countries, however, they still lack a cross country analysis, to find the commonality globally. Hence, this is a novel endeavor as no as the study was conducted with the perspective of global equity markets.

\subsection{Research Objectives}

The following paper examines the effect of financial market volatility on returns of the stock market of different countries of the world. The effect of other macroeconomic factors on the world's Equity Market Indices was also explored. These factors included Consumer Price Index (CPI), Real Interest Rates (R.IR), Market Capitalization (MCAP), and Gross Domestic Product per capita growth (GDPPCG).For analyzing this relationship, around 40 countries data including developed and developing countries, over for 10 years from 2009-2018 which included major ups and downs occurred in the Equity markets of the world. To calculate financial market uncertainty, we followed Chang et al. (2000) methodology, involving cross-sectional absolute standard deviations (CSAD) among individual Countries returns, to define non-linear relations among equity return dispersions and market returns.

\subsection{Research Question}

1. To calculate the uncertainty index for each country 
2. To study the effect of Consumer Price Index, GDP per Capita Growth and Real Interest Rates, market capitalization and uncertainty on stock market returns

3. Cross country comparison of the effect of uncertainty on returns.

\subsection{Significance}

It supports to understanding and explores the association between market uncertainty and stock market returns and makes a clear view about the market uncertainties which occur due to the macro-economic factors fluctuations and related news float in the market furthermore through this study investors can predict and understand the market fluctuations. It also helps to understand, the impact of crises fluctuates across the time frequencies. Through this research judgment which helps policymakers to continuously observe the financial market and fix the macro-economic policies to control the uncertainty effect on market returns.

\section{Literature Review}

(Badshah, et al., 2013; Boscaljan and Clark 2013; Jubinski and Lipton 2013; Sari, Soytas, and Hacihasanoglu, 2011) examined the impact of United State stock market volatility on the markets which were emerging and their results concluded that impact of uncertainty on the standards of fixed income securities, alternative assets, commodities, foreign currencies, and other market volatilities. Rapach, Strauss, and Zhou (2013), and Yunus (2013) discussed the negative relation between the US market returns and stock market uncertainty and cross-market impact of financial uncertainty on emerging markets are less than US market so, lagged US stock returns are a powerful indicator for developed and developing countries.

Dimic et al. (2016) researched to explore the impact of financial market uncertainty and macroeconomic factors on stock market returns, they used Emerging markets along with the US to explore this relationship and they just selected 10 countries of Emerging Markets along with the time zone of 10 years from January 2001 to December 2013 based stock price indices converted into monthly frequencies. They selected all emerging markets in the sample which have positive higher average stock.

Sarwar and Khan (2017) examined the impact of US stock market uncertainty (VIX) on the Stock market returns of Latin America and aggregate and emerging markets who crossed over the financial crises and global equity market crises era. The uncertainty fear leads to higher volatility in stock market returns through generalized autoregressive conditional heteroskedasticity (GAARCH) type process. They were taken data from 2003 to 2014 and covers the crucial time period of financial crises. For this, daily closing uncertainty values from Chicago Board Options Exchange (CBOE) and the daily closing values of Morgan Stanley Capital International (MSCI) emerging market index (EM) and the MSCI country specific index which includes 23 emerging markets. The results shows that, emerging market returns were reduced due to the US market Uncertainty by decreasing the average return and by increasing the variance of a return.

Chulia (2017) established an index for an uncertainty. This index was created after removing the first variation in the series to create the difference between risk and return. For this purpose they sorted 25 portfolios. Then compare it with macro uncertainty and check its 
impact on the dynamics of macro-economic variable. They used Quantile impulse response functions which is taken out from the multivariate quantile to check the results of US market uncertainties on market returns domestic as well as mature and emerging markets also. For this purpose, used data from January 1998 to March 2016 and results revealed that at the time of financial distress, stock market returns reduces due to an uncertainties shocks both in mature and emerging markets.

Fu lai lin (2017) observed the relationship of uncertainty in equity market with the stock and bond relationship that how uncertainty impacts stocks and bonds return. For this study, used data from 1988 to 2014, first to observe the time variation factor between stock and bond relation which can be related in 2 ways like: fundamental economic factors and market uncertainty. The results shows dependency between both of them over the time and effects of uncertainty over the time period of bond relation is negative while the effect of uncertainty over less than one year is positive.

Christou and Cunado (2017) used 6 countries data include (Australia, Canada, China, Japan, Korea and the US) to check the impact of economic policy uncertainty on stock market returns by applying VAR model using Stochastic Search Specific Selection (SSSS). Main concerned towards the Economic Policy Uncertainty shocks and United States Economic Policy Uncertainty shocks as 1998 to 2014 and its results showed that inverse relation occurred between Economic Policy Uncertainty and stock market returns all countries except Australia so it would be beneficial for the investors to invest in these countries after surge in policy uncertainty levels.

Arori (2016) is checked over a long period on US equity market returns. For this relation, used the data determined start from 1900 to 2014 which is a huge time period including world war 1 and 2 plus numerous economic and financial crises to check the true picture of relationship between both variables. They tested the various specifications of Markov switching model: Two regime versus Three regime model but results proved Three regime model is suitable than one and two competing models. Results shows that increase in Economic Policy Uncertainty decreases considerably stock returns and finally concluded that this relation is persistent and stronger throughout highest volatility period.

Xiong et. al. (2018) used unique uncertainty index to check the long term time varying correlation between Economic Policy Uncertainty and Chinese Stock market return. DCC GAARCH model is used to explore this correlation in which examined the data from January 1995 to December 2016. The model revealed that highest fluctuations while the financial crises is going on, furthermore the impact of this uncertainty is more on Shanghai stock market than the Shenzhen stock market and test emphasized over the effects of Economic Policy Uncertainty is larger on State owned Enterprises as differentiate to Non State owned Enterprises. So, during the financial crises correlation drops dramatically and Chinese Stock market crash.

Hoque and Zaidi (2019) in this research, checked the Global Economic Policy Uncertainty on Emerging markets so they checked this impact over Malaysian Market, data taken from 2003 to 2017 by using Linear and Non Linear Models. Using the GAARCH model, they analyze that GEPU negatively affects the Malaysian Stock market. But equity market enactment in both short and tall uncertain positions which effect by the Global Policy Uncertainty and this 
is uncovered by Markov switching estimation. So, the relationship both the variables GEPU and stock markets returns tends to be asymmetric.

\subsection{Market Uncertainty}

Helena Chuliá, Montserrat Guillén, Jorge M. UribeFrank (2016) discussed many theories related to Uncertainty in which Knight suggest difference between uncertainty and risk in a clear way that the earlier cannot be described by means of a probability measure while the latter can. So, the dissimilarity between the risk and uncertainty is still a debating topic. Indeed several studies were conducted over it to explore this difference. While we discussed about the empirical studies they mostly relied on proxies of uncertainties which are directly observable like stock return of their implied/realized volatility (i-e., VIX or VXO) the cross sectional dispersion of firms profits (Bloom, 2009), estimated time-varying productivity (Bloom et al., 2013), the cross-sectional dispersion of survey-based forecasts (Dick, Schmeling, \& Schrimpf, 2013; Bachmann, Elstner, \& Sims, 2013), credit spreads (Fendoğlu, 2014). On the other hand (Scotti, 2016 they provide crucial intuitions to the comprehension of uncertainty and serve as a dependable starting point for exploring the reasons of hitting economic variables by the uncertainty in an economy.

Latanè, H. A., and Rendleman (1976) discussed "The option pricing model" that's given by Black and Scholes (B-S) which gained a so much popularity in both academics and investments. By using this model researcher used the standard deviations of continuous price relative returns which are implied in actual call option prices on the assumption that investors behave as if they price options and this measure which is Implied Standard Deviations (ISDs) used as measure of Market forecast of return uncertainty and then this measured is used for several purpose to measure its impacts on returns and to check the sensitivity of an option price to movements in the underlying stocks.

Rustam Boldanov, Stavros Degiannakis, George Filis (2016) in their study they calculate market monthly volatilities on the bases of six stock market indices by collecting a data from January 2000 through to December 2014. The six market indices represent three oil-exporting countries (TSX (Canada), RTS (Russia), OSEAX (Norway)) and three oil-importing countries (S\&P 500 (the US), SSE (China) and Nikkei 225 (Japan)). The calculated volatilities are offered as conditional volatilities which can be defined as conditional standard deviation of returns.

We followed Chang et al. (2000) methodology, which involves cross-sectional absolute standard deviations (CSAD) among sample Countries returns, to define non-linear relations among equity return dispersions and market returns.

$$
\mathrm{CSAD}=\sqrt{ } \sum\left(\mathrm{R}_{\mathrm{i}, \mathrm{t}}-\mathrm{R}_{\mathrm{m}, \mathrm{t}}\right)^{2} / \mathrm{N}-1
$$

Where $R_{i ; t}$ is the observed stock return on firm $i$ at time $t$ and $R_{m, t}$ is the cross-sectional average of the $\mathrm{N}$ returns in the aggregate market returns at time t. This dispersion measure quantities the average proximity of individual returns to the realized average 


\section{Uncertainty Values:}

\begin{tabular}{|c|c|c|c|c|c|c|c|c|c|c|c|c|}
\hline & 2009 & 2010 & 2011 & 2012 & 2013 & 2014 & 2015 & 2016 & 2017 & 2018 & $\begin{array}{l}\text { High Value } \\
\text { period }\end{array}$ & Events coinciding to this period \\
\hline Egypt & 0.019 & 0.015 & 0.023 & 0.016 & 0.012 & 0.011 & 0.012 & 0.011 & 0.009 & 0.009 & 2011 & Egyptian Revolution of 2011 \\
\hline Nigeria & 0.000 & 0.000 & 0.000 & 0.007 & 0.004 & 0.001 & 0.018 & 0.009 & 0.011 & 0.009 & 2015 & Election of 2015 \\
\hline Bangladesh & 0.000 & 0.000 & 0.000 & 0.000 & 0.014 & 0.008 & 0.003 & 0.002 & 0.000 & 0.004 & 2013 & Impact of market crash in 2010-2011 \\
\hline India & 0.000 & 0.000 & 0.012 & 0.014 & 0.005 & 0.003 & 0.003 & 0.005 & 0.003 & 0.005 & 2012 & Indian Blackouts of July 2012 \\
\hline Pakistan & 0.033 & 0.004 & 0.005 & 0.003 & 0.004 & 0.006 & 0.008 & 0.007 & 0.005 & 0.006 & 2009 & $\begin{array}{l}\text { IMF package and improve } \\
\text { economic conditions }\end{array}$ \\
\hline Indonesia & 0.002 & 0.011 & 0.002 & 0.008 & 0.005 & 0.007 & 0.002 & 0.010 & 0.007 & 0.002 & 2010 & Major Floods, Earth Quakes and Tsunami \\
\hline Lebanon & 0.000 & 0.003 & 1.031 & 0.002 & 0.001 & 0.000 & 0.001 & 0.001 & 0.001 & 10.492 & 2018 & Banks suck in dollar to maintain Peg \\
\hline Namibia & 0.000 & 0.000 & 0.000 & 0.000 & 0.011 & 0.010 & 0.015 & 0.017 & 0.010 & 0.013 & 2016 & $\begin{array}{l}\text { Fiscal consolidation process started in } \\
\text { the mid and technical recession }\end{array}$ \\
\hline Oman & 0.016 & 0.005 & 0.007 & 0.005 & 0.005 & 0.010 & 0.006 & 0.006 & 0.004 & 0.004 & 2009 & Decline in Oil prices declines Economy \\
\hline Colombia & 0.021 & 0.016 & 0.019 & 0.015 & 0.016 & 0.016 & 0.017 & 120.826 & 159.668 & 115.839 & 2017 & QE program and Capital market reforms \\
\hline United states & 0.000 & 0.011 & 0.014 & 0.067 & 4.556 & 0.007 & 0.010 & 0.008 & 0.004 & 0.010 & 2013 & World's highest CAPE ratio \\
\hline South Africa & 0.017 & 0.012 & 0.013 & 0.008 & 0.010 & 0.009 & 0.011 & 0.011 & 0.007 & 0.012 & 2009 & $\begin{array}{l}\text { Impact of Global Financial and } \\
\text { Economic crises }\end{array}$ \\
\hline Ukraine & 0.022 & 0.020 & 0.018 & 0.014 & 0.011 & 0.019 & 0.011 & 0.008 & 0.003 & 0.020 & 2009 & Stock markets merger \\
\hline Singapore & 0.010 & 0.013 & 0.013 & 0.011 & 0.009 & 0.008 & 0.013 & 0.011 & 0.007 & 0.011 & 2010 & $\begin{array}{l}\text { Sudden decline in GDP growth } \\
\text { rate in a quarter }\end{array}$ \\
\hline Qatar & 0.000 & 0.000 & 0.000 & 0.004 & 0.008 & 0.017 & 0.013 & 0.013 & 0.012 & 0.014 & 2014 & $\begin{array}{l}\text { In the pace to clinch the Region's best } \\
\text { performer tag from Dubai }\end{array}$ \\
\hline Romania & 0.000 & 0.000 & 0.017 & 0.010 & 0.007 & 0.007 & 0.008 & 0.008 & 0.006 & 0.011 & 2011 & Faced Economic Crises \\
\hline Philippines & 0.000 & 0.000 & 0.000 & 0.014 & 0.016 & 0.006 & 0.013 & 0.017 & 0.009 & 0.014 & 2016 & El Niño H1 and wide spread of dengue \\
\hline New Zealand & 0.008 & 0.005 & 0.006 & 0.063 & 0.005 & 0.005 & 0.005 & 0.006 & 0.004 & 0.006 & 2012 & Impact of Global crises \\
\hline Mexico & 0.012 & 0.008 & 0.012 & 0.007 & 0.010 & 0.008 & 0.008 & 0.008 & 0.007 & 0.017 & 2018 & Disruptive trade wars \\
\hline Sri lanka & 0.012 & 0.009 & 0.012 & 0.007 & 0.010 & 0.008 & 0.009 & 0.009 & 0.006 & 0.010 & 2009 & End of the Sri Lankan Civil War \\
\hline Kenya & 0.000 & 0.000 & 0.000 & 0.000 & 0.000 & 0.034 & 0.018 & 0.019 & 0.022 & 0.022 & 2014 & Continuous net debt risen \\
\hline Japan & 0.015 & 0.011 & 0.014 & 0.009 & 0.015 & 0.012 & 0.014 & 0.017 & 0.007 & 0.013 & 2016 & $\begin{array}{l}\text { Sudden increase in yen value } \\
\text { and restrictions of } \\
\text { government intervention }\end{array}$ \\
\hline Jordan & 0.000 & 0.000 & 0.000 & 0.010 & 0.011 & 0.011 & 0.015 & 0.009 & 0.007 & 0.012 & 2018 & Economic disaster \\
\hline Hungary & 0.000 & 0.000 & 0.018 & 0.013 & 0.010 & 0.011 & 0.012 & 0.010 & 0.008 & 0.011 & 2011 & Decline in investment rate \\
\hline
\end{tabular}




\begin{tabular}{|c|c|c|c|c|c|c|c|c|c|c|c|c|}
\hline Thailand & 0.016 & 0.011 & 0.014 & 0.008 & 0.013 & 0.008 & 0.009 & 0.009 & 0.004 & 0.008 & 2009 & Underlying Credit Bubble \\
\hline China & 0.000 & 0.000 & 0.000 & 0.000 & 0.000 & 0.018 & 0.030 & 0.018 & 0.008 & 0.015 & 2015 & Chinese stock market turbulence \\
\hline Chile & 0.008 & 0.006 & 0.011 & 0.005 & 0.008 & 0.006 & 0.007 & 0.006 & 0.009 & 0.006 & 2011 & $\begin{array}{l}\text { uncertainties due to the } \\
\text { European debt crisis }\end{array}$ \\
\hline Canada & 0.016 & 0.008 & 0.012 & 0.007 & 0.006 & 0.006 & 0.009 & 0.008 & 0.005 & 0.007 & 2009 & $\begin{array}{l}\text { the Canadian economy } \\
\text { entered a recession }\end{array}$ \\
\hline Brazil & 0.016 & 0.011 & 0.014 & 0.010 & 0.009 & 0.012 & 0.011 & 0.013 & 0.011 & 0.012 & 2009 & FX intervention boosts \\
\hline Hong Kong & 0.000 & 0.000 & 0.021 & 0.011 & 0.010 & 0.009 & 0.013 & 0.012 & 0.007 & 0.012 & 2015 & crash of Chinese stocks on the Mainland \\
\hline Bulgaria & 0.000 & 0.000 & 0.046 & 0.035 & 0.028 & 0.035 & 0.035 & 0.038 & 0.027 & 0.029 & 2011 & Global Shares Rout \\
\hline Australia & 0.013 & 0.010 & 0.012 & 0.007 & 0.008 & 0.007 & 0.010 & 0.009 & 0.006 & 0.007 & 2009 & The Equity issue \\
\hline Croatia & 0.013 & 0.010 & 0.012 & 0.007 & 0.007 & 0.007 & 0.010 & 0.009 & 0.006 & 0.007 & 2009 & The Case of Croatia \\
\hline Korea, Rep. & 0.000 & 0.000 & 0.019 & 0.010 & 0.008 & 0.007 & 0.008 & 0.008 & 0.006 & 0.009 & 2011 & Quick economic recovery \\
\hline Mauritius & 0.000 & 0.000 & 0.019 & 0.010 & 0.008 & 0.007 & 0.008 & 0.008 & 0.006 & 0.009 & 2011 & Foundation of SEM \\
\hline Namibia & 0.008 & 0.009 & 0.016 & 0.003 & 0.011 & 0.007 & 0.011 & 0.010 & 0.016 & 0.016 & $\begin{array}{l}2011 \\
17,18\end{array}$ & Drop in uranium revenues \\
\hline $\begin{array}{l}\text { Russian } \\
\text { Federation }\end{array}$ & 0.030 & 0.015 & 0.017 & 0.012 & 0.010 & 0.015 & 0.013 & 0.010 & 0.008 & 0.011 & 2009 & Fall of Russia's (FXR) \\
\hline Vietnam & 0.000 & 0.000 & 0.000 & 0.000 & 0.000 & 0.012 & 0.009 & 0.008 & 0.006 & 0.014 & 2018 & "Escalating Trade War" \\
\hline
\end{tabular}

EGYPT: Hosni Mubarak was in power under emergency law and protests in Tunisia sparked by the death of Mohamed Bou Azizi turned into a revolution including the demise of Khaled Saeed. Due to all these protest waves it causes high unemployment, an increase in inflation rate, and low minimum wages which directly hits EGX and causes volatilities.

NIGERIA: Muhammdu Buhari wins The Election of 2015, so The Nigeria Stock market marked for stronger growth in 2015, this Election help to build investors' confidence again.

BANGLADESH: The Bangladesh stock market crash in 2010-2011, some market observers sounding the alarm of a potential bubble in Bangladesh markets. Due to this GDP growth rate recorded at $6.01 \%$ lowest in 2013.

INDIA: In the history of mankind it was the worst power crises in which two large scale power Blackouts in India in which around 350 million people were affected, while the second one involved a whopping 670 million people, one-tenth of the world's population and spread over 21 out of 28 Indian states.

PAKISTAN: After 2008, growth slowed due to the downturn and collapse of world demand but in 2009 it started improving after the IMF bailout package economy gradually moving upward GDP growth rate recorded above the $3 \%$ and inflation decrease from $25 \%$ to $14 \%$ from 
INDONESIA: This year 2010, was majorly a disturbance year for Indonesia because in April Sumatra Earthquake, in June Papua Earthquake and in October Mentawai Earthquake and Tsunami which create disturbance in the economy and ultimately affect financial markets.

LEBANON: Banks are removing the barriers to bring in dollars as they want to save a two-decade old currency peg, which resultantly offers high returns to customers to change their hard currency into the long term.

NAMIBIA: Due to the excess spending's in previous fiscal years continued to future years with slower space. Along with this due to the technical recession economic deterioration during which trade and industrial activity are concentrated, generally identified by a fall in GDP in two successive quarters.

OMAN: Change in GDP was mainly due to the decline in oil prices. Matrah Souk in Muscat. Oman's GDP per capita income fell to about RO6000 in 2009 from RO8000 in 2008.

COLOMBIA: In short it's an implementation of "Money Printing" in which liquidity increase by the Central bank in the financial system. It ultimately affects the financial system of the economy and the real economy be selling the additional bonds.

UNITED STATES: World's Highest CAPE ratio reason for this higher rate of share repurchases.

SOUTH AFRICA: Warnings to enlarged asset price and risk premium rates which caused volatilities in the financial markets of Africa since 2008.

UKRAINE: Due to the Stock market mergers in 2009, outclass performance recorded because before this 10 stock markets were working in the same country.

SINGAPORE: Singapore is counted in four Asian tigers and highly developed with free-market economy that's why it enjoys high GDP rate than other developed countries but a sudden decline in GDP growth rate from 44.50\% in March 2010 to - $18.90 \%$ in September of 2010.

QATAR: Sudden positive changes were seen in the QSE market and this moment was started with the start of FY14.

ROMANIA: 2011 called a changing year for Romania, by changing the political regime which is continued from years to years by rearranging the economic social system, transition enforced by crisis, disproportion, and economic loss.

PHILIPPINES: Poverty, geographical remoteness, rapid urbanization, malnutrition, and poor hygiene, and sanitation all are causal factors of wide-spread of dengue. Other than this Philippines is also affected by El Niño H12 because of this agriculture sector is affected and PPP (Public-Private Partnership) projects were delayed.

NEW ZEALAND: In late 2008 and early 2009, it's the phase of global crises that caused a rapid deterioration in the financial and economic activities of overall countries of the world.

MEXICO: All the mishaps occurred in 2018 when the Fed increases the rates drastically so, it impacts the economy by slowing down their 
activities.

SRILANKA: It was a great time started after the end of the Civil war in Srilanka in 2009, after this economy started flourishing again by touching its peak, the CSE index followed new bullish records like in October 2009 it touched the RS. 1 Trillion Marks first time.

KENYA: Kenya's economy faces a continuous rise in the debt to GDP ratio after 2012 and in 2016 it reaches $53.46 \%$ so it badly impacts the financial markets and liquidity position in the market.

JAPAN: 2008 is the worst year for the Nikkei stock exchange due to the global financial crises if faced huge losses and bearish trends. Due to the fear of this crisis exchange fell by $4.84 \%$, including this the value of the yen is rising and followed the biggest weekly crash.

JORDAN: In 2018, Jordanians faced heavy economic disaster because they were demanding the resignation of the government and the parliament termination.

HUNGARY: It has low stability in exchange rate with the US dollar sometimes fluctuations as large as a 50\% decline in GDP can be seen due to the external shocks and government.

THAILAND: Thailand's economy faced troubles due to the Underlying Credit Bubble. It marked as a most effecting bubble for Thailand's economy by increasing consumer spending and more money in the economy. The Domestic demand of the company is replaced by the export sector.

CHINA: when the Bubble burst in 2015, it was the starting of turbulence in the Chinese stock market and it holds up till the end of 2016 and due to this value of A-shares was lost within February.

CHILE: due to fears of conation of the European sovereign debt crisis. The August 2011 stock markets drop was the sharp decline in stock prices in August 2011 in stock exchanges across the United States, Middle East, Europe, and Asia.

CANADA: Due to the Global Financial Crises occurred between 2008-2009 caused a lack of confidence in investors and the global financial sector which badly affect the economy of Canada.

BRAZIL: Brazil stocks jump 7\% in the biggest gain since 2009, FX intervention boosts real.

HONG KONG: Crash in the Chinese stock market is badly affects the overall situation in the market which causes the result throughout the year was a slide in the HSI from a peak of 28,442 on April 28 to a bottom of 20,556 on September 28 - a 25 percent drop Bulgarian.

AUSTRALIA: Equity capital markets in the 2009 calendar year to date, Australian companies raised a record $\$ 96$ billion in initial .and subsequent equity issues. Despite representing only 2-3\% of global equity market value, so recognized as the third most active capital market in the world.

CROATIA: Real GDP, M1/GDP ratio have a positive relationships with the stock market index, and German stock market index and the euro area government bond yield have a negative relation with the ratio of the government deficit to GDP, the domestic real interest rate, the 


\section{Macrothink}

Business and Economic Research ISSN 2162-4860

HRK/USD exchange rate, and the expected inflation rate.

KOREA, REP: After the global financial crises South Korea still has the power to come back and restart rising growth rates which promotes its GDP rate to double since 1998.

MAURITIUS: In the history of Mauritius its SEM gets a title in 2011 for serving a multi-currency platform which is too rare in the world, now they can deal in a dual currency which is helpful to flourish their economy.

NAMIBIA: 2018 February -the economy of Namibia has been hit by a decline in uranium revenues including this to cutting expenditures all foreign business travel is banned for civil servants and politicians.

RUSSIAN FEDERATION: Major reason for uncertainty in the financial markets of Russian federation is a certain to decline in reserves of foreign exchange from $\$ 386$ billion to $\$ 210$ billion.

VIETNAM: It was a situation that only deteriorates going downwards. It hit a drop of nearly $18 \%$ in a quarter and has marked as the worst period of the market 


\section{SCATTERPLOT GRAPH ON UNCERTAINTY VS RETURN:}

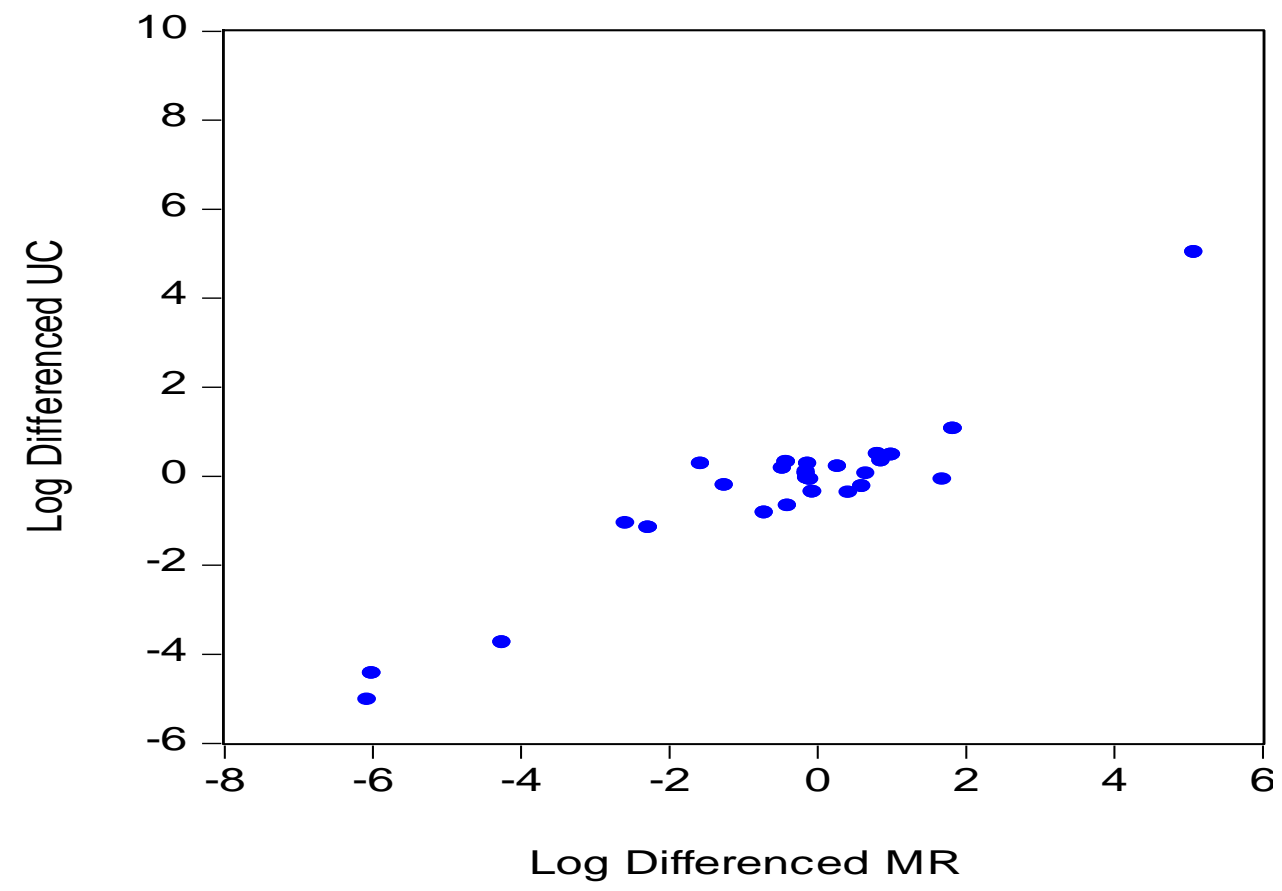

In this graph, on y-axis take Uncertainty and on x-axis Market return and this is shown that when the uncertainty change which can be seen through log difference of uncertainty it also pushes market return with it with the same proportion.

\section{GRAPH ON UNCERTAINTY VS WORLD UNCERTAINTY INDEX:}

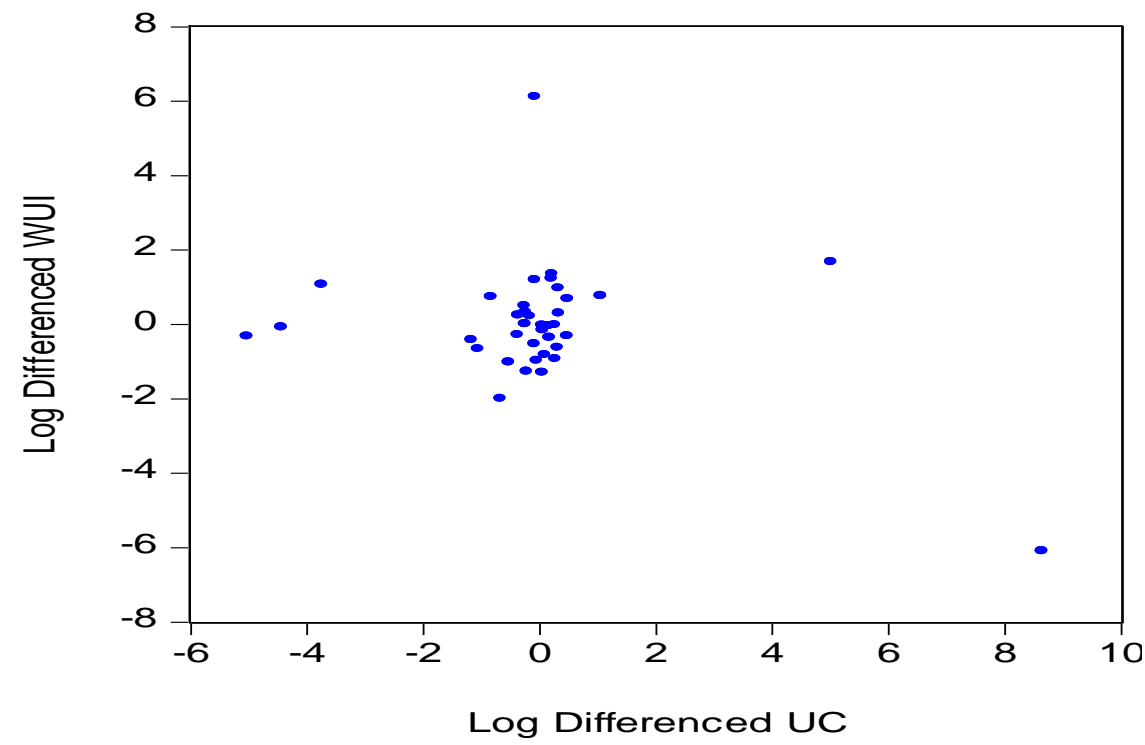

In this graph, analysis of two different measures in which one has calculated Market uncertainty according to the prescribed methodology and the other one is World Uncertainty Index which is a new index of 143 countries quarterly from 1999 to onwards but we used data from 2009 to 2018 and analyze that both the measures are showing the same spark of 
changes in the duration.

\section{TREND ANALYSIS:}

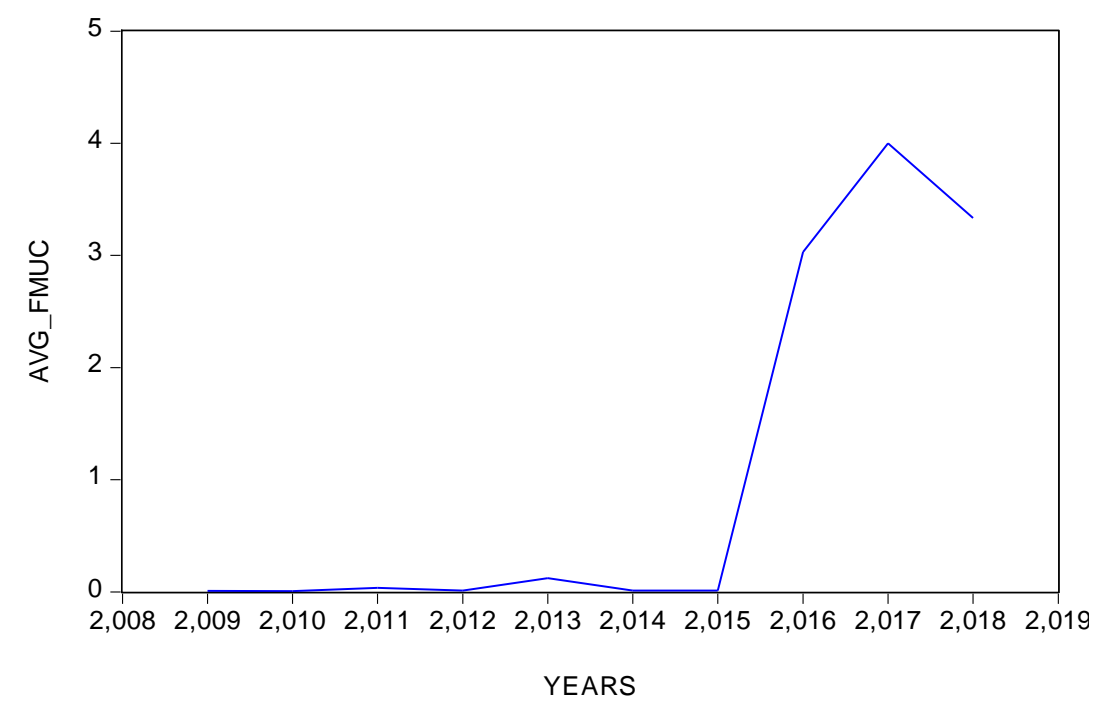

In the time-series graph, analyse the changes in financial market uncertainty from time to time. Like it covers the era from 2009 to 2018, in which major changes occur in between 2015 to 2018 which major reasons are Euro debt crises, El Nino, UK Brexit vote, and 2016 US Elections which impact overall the world.

\subsection{Real Interest Rate: (R.Ir)}

According to the study, Chandra (2004) rise in interest rates indicates to depress in corporate profitability and rise in discount rates implement to equity investors which have a negative impact on stock prices. Another theoretical perspective is, either the interest rates are short term or long term it negatively responds to stock returns (French et al, 1987).

\subsection{Consumer Price Index: (Cpi)}

Fama (1991) examines that expected inflation is negatively related to the share prices. It implies that the inflation rate is negatively related to US stock prices and have a positive relationship with the economic activity (Geske and Roll, 1983).

\subsection{Gross Domestic Product: (GDP Per Capita Growth)}

Carstrom (2002) examines the relationship between future RGDP growth and stock prices. According to him, changes in real GDP cause changes in stock market prices and further add changes in stock prices will decrease a firm's assets worth and distress the cost of their borrowing.

\subsection{Market Capitalization}

The impact of market capitalization on returns extends beyond a comparison of small- and large-cap stocks. Marc R. Reinganum (1999) explored this relationship between the market capitalizations and return and concluded that over long investment horizons, smaller-cap stocks outperform large-cap stocks, although there is much variability around this long-run 
relationship in shorter investment horizons.

\subsection{Equity Market Return: (MR)}

Investors of different financial capacity can invest in the stock market as long as they can get a return that is higher than their cost of capital (Wang, 2012).

Market Indices return data of different countries taken on a daily basis from their country's stock exchange website.

\section{Methodology}

The data regarding stock market returns, CPI, GDP per capita growth, real interest rates, market capitalization, and market uncertainty have been taken for the last 10 years from 2009-2018. We have taken 40 different countries Equity Market Indices (dependent variable) for the period of 2009 to 2018 on a yearly basis and Market Uncertainty through CSAD model and Consumer Price Index, GDP per capita growth, Market Capitalization, and Real Interest rates data (independent variable).

The model is specified below:

$\mathrm{MR}=\mathrm{C}(\mathrm{MU}, \mathrm{MCAP}, \mathrm{R} . \mathrm{IR}, \mathrm{GDPPCG}, \mathrm{CPI})$

This can be represented in the equation as:

$\mathrm{MR}=$ Constant $+\beta$ (Market uncertainty) $+\beta$ (Real Interest rates) $+\beta$ (GDP per capita growth) $+\beta$ (Consumer Price Index $)+\beta$ (Market Capitalization)

\subsection{Descriptive Statistics}

The descriptive analyses were conducted to know the mean, median, standard deviation, Skewness, kurtosis, and the like statistics.

Overall Descriptive Analysis for market return and financial market uncertainty

\begin{tabular}{|l|c|c|c|c|c|c|}
\hline & MR & UC & IR & MCAP & GDP & CPI \\
\hline Mean & 0.295245 & 1.040464 & 4.755858 & $1.40 \mathrm{E}+12$ & 1.896824 & 4.183864 \\
\hline Median & 0.000133 & 0.008858 & 3.865993 & $1.31 \mathrm{E}+11$ & 2.154189 & 3.395661 \\
\hline Maximum & 57.49986 & 159.6679 & 43.34256 & $3.21 \mathrm{E}+13$ & 10.10310 & 48.69986 \\
\hline Minimum & -0.004290 & 0.000000 & -13.10057 & 0.000000 & -14.37929 & -4.863278 \\
\hline Std. Dev. & 3.552919 & 11.54814 & 6.866215 & $4.00 \mathrm{E}+12$ & 3.150877 & 4.382600 \\
\hline Skewness & 13.32569 & 11.77033 & 2.864503 & 5.266466 & -0.709018 & 3.649647 \\
\hline Kurtosis & 192.5716 & 143.0737 & 15.63201 & 33.61803 & 4.846470 & 31.70036 \\
\hline
\end{tabular}

*This table presents the summary statistics for market return, financial market uncertainty, Real Interest rates, Market Capitalization, Gross Domestic Product per capita growth, and Consumer Price Index covering the data period from January 2009 to December 2018. 


\section{Macrothink Institute ${ }^{\mathrm{m}}$}

Business and Economic Research

ISSN 2162-4860

2020, Vol. 10, No. 3

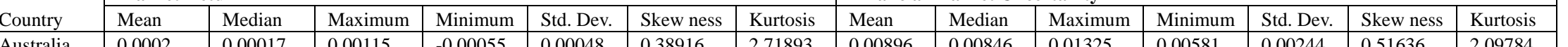

\begin{tabular}{|l|l|l|l|l|l|l|l|l|}
\hline & 0.00017 & 0.00115 & -0.00055 & 0.00048 & 0.38916 & 2.71893 & 0.00896 & 0.00 \\
\hline
\end{tabular}

\begin{tabular}{|l|l|l|l|l|l|l|l|l|l|l|l|l|l|l|l|l} 
Bangladesh & 0.00012 & 0 & 0.00088 & -0.0005 & 0.0004 & 0.22031 & 2.84448 & 0.00305 & 0.00091 & 0.014 & 0 & 0.0045 & 1.5392 & 4.272 \\
\hline
\end{tabular}

\begin{tabular}{|l|l|l|l|l|l|l|l|}
\hline Brazil & 0.00054 & 0.000232 & 0.002228 & -0.0001 & 0.000698 & 1.4587 & 4.3856 \\
\hline & 0.0008 & 0.00077 & 0.00326 & -0.00306 & 0.00188 & -0.70151 & 3.2107 \\
\hline
\end{tabular}

\begin{tabular}{ll|l|l|l|l}
\hline Bulgaria & 0.00098 & 0.00077 & 0.00326 \\
\hline Canad & 0.000227 & 0.000275 & 0.001202 \\
\hline
\end{tabular}

\begin{tabular}{|l|l|l|l|l|l|l|l|}
\hline Canada & 0.000227 & 0.000275 & 0.001202 & -0.00306 & 0.00188 & -0.70151 & 3.2107 \\
\hline Chile & 0.00036 & 0.00017 & 0.00158 & -0.00056 & 0.00078 & 0.4078 & 1.6987
\end{tabular}

\begin{tabular}{|l|l|l|l|}
\hline Canada & 0.000227 & 0.000275 & 0.001202 \\
\hline Chile & 0.00036 & 0.00017 & 0.00158 \\
\hline China & 0.000194 & 0 & 0.00199
\end{tabular}

\begin{tabular}{|l|l|l|l|l|l|l|}
\hline 0.01176 & 0.01152 & 0.01552 & 0.00924 & 0.00189 & 0.554285 & 2.62907 \\
\hline 0.0272 & 0.0319 & 0.0464 & 0 & 0.01542 & -0.98827 & 2.7485 \\
\hline
\end{tabular}

\begin{tabular}{l|l|l|l|}
\hline & 0.000194 & 0 & 0.00199 \\
\hline Colombia & 11.686 & 0.0011 & 57.4998 \\
\hline
\end{tabular}

\begin{tabular}{ll|l|l|l|} 
Colombia & 11.686 & 0.0011 & 57.49 \\
\hline Croatia & 0.0001 & 0.0001 & 0.001 \\
\hline
\end{tabular}

\begin{tabular}{|l|l|l|l|l|l|l|l|}
\hline Egypt & 0.00038 & 0.0007 & 0.00245 & -0.0026 & 0.00146 & -75807 & 2.88459 \\
\hline Hong Kong & 0.000156 & 0.000101 & 0.001305 & -0.00062 & 0.00057 & 0.68309 & 2.859
\end{tabular}

\begin{tabular}{lllll} 
Hungary & 0.000244 & $7.66 \mathrm{E}-05$ & 0.001528 & -0.1 \\
\hline & 0.0002 & 0.0001 & 0.0011 & -0.1
\end{tabular}

\begin{tabular}{l|l|l|}
0.0002 & 0.0001 & 0.0011 \\
\hline 0.00075 & 0.000575 & 0.003397 \\
\hline
\end{tabular}

\begin{tabular}{ll|l|l|l|l} 
Indonesia & 0.00075 & 0.000575 & 0.003397 \\
\hline
\end{tabular}

\begin{tabular}{l|l|l|l|} 
Japan & 0.0003 & 0.0004 & 0.0017 \\
\hline
\end{tabular}

\begin{tabular}{l|l|l|l|l|l}
\hline Jordan & 0.0005 & -9.598 & 0.0059 \\
\hline
\end{tabular}

\begin{tabular}{|l|l|l|l|l|l|l|l|}
\hline Jordan & -0.00014 & $-5.10 \mathrm{E}-05$ & 0.000348 & -0.0009 & 0.00036 & -0.5518 & 7.741 \\
\hline Kena & 0.00041 & 0 & 0.0035 & -0.00098 & 0.0013 & 1.4346 & 4.0798 \\
\hline
\end{tabular}

\begin{tabular}{|l|l|l|l|l|l|l|l|l|l|l|l|l|l|l} 
Jordan & -0.00014 & $-5.10 \mathrm{E}-05$ & 0.000348 & -0.0009 & 0.00036 & -0.728 & 3.0798 & 0.00748 & 0.00928 & 0.01495 & 0 \\
\hline Kenya & 0.00041 & 0 & 0.0035 & -0.00098 & 0.0013 & 1.4346 & 4.403 & 0.011468 & 0.009214 & 0.034062 & 0 \\
\hline Korea.Rep & $-5.56 \mathrm{E}-05$ & 0 & 0.00098 & -0.00111 & 0.00059 & -0.18817 & 2.7201 & 0.0076 & 0.00793 & 0.01896 & 0 \\
\hline Lebanon & 0.081232 & 6.53888 & 0.741426 & -0.00014 & 0.233022 & 2.623873 & 7.96891 & 1.1532 & 0.0013 & 10.4915 & 0 \\
\hline
\end{tabular}

\begin{tabular}{|l|l|l|l|l|l|l|l|l|l|l|l|l|l|}
\hline Mauritius & $-5.57 \mathrm{E}-05$ & 0 & 0.00098 & -0.0011 & 0.00059 & -0.18817 & 2.7201 & 0.0076 & 0.00793 & 0.01896 & 0 \\
\hline & 0.0035 & 0.0031 & 0.00092 & $8.00 \mathrm{E}-05$ & 0.00024 & 1.2076 & 4.078 & 0.009754 & 0.008342 & 0.016943 & 0.00 \\
\hline
\end{tabular}

\begin{tabular}{|l|l|l|l|l|l|l|l|l|l|l|l|l|l}
\hline Mauritius & $-5.57 \mathrm{E}-05$ & 0 & 0.00098 & -0.001 & 0.0059 & -0.18817 & 2.7201 & 0.0076 & 0.00793 & 0.01896 & 0 \\
\hline Mexico & 0.00035 & 0.00031 & 0.00092 & $8.00 \mathrm{E}-05$ & 0.00024 & 1.2076 & 4.078 & 0.009754 & 0.008342 & 0.016943 & 0.0065
\end{tabular}

\begin{tabular}{|c|c|c|c|c|c|c|c|c|c|c|c|c|c|c|}
\hline & & & & & & & & & & & & & & \\
\hline Zealand & -0.00013 & 0.00028 & 0.00066 & -0.0032 & 0.0012 & -2.093 & 5.7004 & 0.0125 & 0.0056 & 0.0632 & 0.004 & 0.0204 & 2.261 & 6.1258 \\
\hline Namibia & 0.00018 & $5.52 \mathrm{E}-05$ & 0.0009 & $\begin{array}{l}-0.0008 \\
\end{array}$ & 0.0005 & -0.28 & 3.0899 & 0.0075 & 0.0098 & 0.0168 & 0 & 0.0068 & -0.101 & 1.3802 \\
\hline Namibia & 0.0031 & 0.0028 & 0.0071 & 0.00062 & 0.00175 & 1.026 & 3.9249 & 0.0107 & 0.01049 & 0.01647 & 0.0025 & 0.00454 & -0.1471 & 2.2725 \\
\hline Nigeria & 0.00018 & 0 & 0.0016 & -0.0009 & 0.00094 & 0.50064 & 1.74982 & 0.0059 & 0.0055 & 0.0183 & 0 & 0.006 & 0.6974 & 2.5881 \\
\hline Oman & $-6.00 \mathrm{E}-05$ & -0.0001 & 0.0007 & -0.0006 & 0.00055 & 0.294 & 1.62297 & 0.007 & 0.005 & 0.016 & 0.004 & 0.003 & 1.766 & 5.018 \\
\hline Pakistan & 0.0008 & 0.001 & 0.002 & -0.0005 & 0.0009 & -0.2162 & 1.5098 & 0.007 & 0.005 & 0.0325 & 0.0025 & 0.0087 & 2.4979 & 7.5834 \\
\hline Philippines & -0.00018 & $-2.58 \mathrm{E}-05$ & 0.00031 & -0.00109 & 0.00039 & -1.1703 & 3.8282 & 0.00898 & 0.011 & 0.01683 & 0 & 0.00696 & -0.3412 & 1.4659 \\
\hline Qatar & 4.63E-05 & 0 & 0.00117 & -0.00118 & 0.00079 & -0.0097 & 1.928 & 0.00815 & 0.0096 & 0.0169 & 0 & 0.0066 & -0.1811 & 1.4426 \\
\hline Rfeder & 0.000652 & 0.00039 & 0.00363 & -0.00059 & 0.00118 & 1.64095 & 5.1812 & 0.014 & 0.0125 & 0.0299 & 0.0083 & 0.0061 & 1.7934 & 5.4594 \\
\hline Romania & 0.00025 & 0.00013 & 0.00085 & -0.0002 & 0.0003 & 0.5081 & 2.0386 & 0.00754 & 0.0075 & 0.0174 & 0 & 0.005 & 0.1461 & 2.9664 \\
\hline Africa & 0.00041 & 0.00044 & 0.00114 & -0.00039 & 0.00048 & -0.194 & 2.01 & 0.01106 & 0.0114 & 0.0169 & 0.007 & 0.0027 & 0.583 & 3.1408 \\
\hline Singapore & $-1.90 \mathrm{E}-05$ & $7.14 \mathrm{E}-05$ & 0.00059 & -0.00118 & 0.0004 & -1.4569 & 4.9926 & 0.0104 & 0.0107 & 0.013 & 0.0065 & 0.0021 & -0.41 & 2.0647 \\
\hline Srilanka & 0.0003 & 0.00017 & 0.0017 & -0.00061 & 0.0006 & 0.9166 & 3.676 & 0.009291 & 0.008918 & 0.012492 & 0.00626 & 0.002059 & 0.29668 & 2.1111 \\
\hline Thailand & 0.000567 & 0.00057 & 0.0021 & -0.00058 & 0.00088 & 0.3284 & 2.0865 & 0.00999 & 0.00881 & 0.01585 & 0.00406 & 0.00356 & 0.1806 & 2.205 \\
\hline Thailand & 0.00021 & 0.000287 & 0.000897 & -0.00049 & 0.000426 & -0.09576 & 2.0602 & 0.00986 & 0.00984 & 0.01474 & 0.00541 & 0.00293 & 0.23417 & 2.07917 \\
\hline Ukraine & 0.00036 & 0.00056 & 0.00282 & -0.00226 & 0.0019 & -0.1346 & 1.6083 & 0.0145 & 0.0156 & 0.0217 & 0.0028 & 0.00621 & -0.5594 & 2.1521 \\
\hline US & 0.0288 & 0.0002 & 0.2914 & -0.0042 & 0.0922 & 2.665 & 8.107 & 0.4686 & 0.0097 & 4.556 & 0 & 1.436 & 2.665 & 8.1084 \\
\hline Viet & $4.94 \mathrm{E}-05$ & 0 & 0.0016 & -0.0013 & 0.00072 & 0.5475 & 4.5585 & 0.004 & 0.003 & 0.013 & 0 & 0.005 & 0.3706 & 1.548 \\
\hline
\end{tabular}

\begin{tabular}{|c|c|c|c|c|c|c|c|c|c|c|c|c|c|c|}
\hline & & & & & & & & & & & & & & \\
\hline Zealand & -0.00013 & 0.00028 & 0.00066 & -0.0032 & 0.0012 & -2.093 & 5.7004 & 0.0125 & 0.0056 & 0.0632 & 0.004 & 0.0204 & 2.261 & 6.1258 \\
\hline Namibia & 0.00018 & $5.52 \mathrm{E}-05$ & 0.0009 & $\begin{array}{l}-0.0008 \\
\end{array}$ & 0.0005 & -0.28 & 3.0899 & 0.0075 & 0.0098 & 0.0168 & 0 & 0.0068 & -0.101 & 1.3802 \\
\hline Namibia & 0.0031 & 0.0028 & 0.0071 & 0.00062 & 0.00175 & 1.026 & 3.9249 & 0.0107 & 0.01049 & 0.01647 & 0.0025 & 0.00454 & -0.1471 & 2.2725 \\
\hline Nigeria & 0.00018 & 0 & 0.0016 & -0.0009 & 0.00094 & 0.50064 & 1.74982 & 0.0059 & 0.0055 & 0.0183 & 0 & 0.006 & 0.6974 & 2.5881 \\
\hline Oman & $-6.00 \mathrm{E}-05$ & -0.0001 & 0.0007 & -0.0006 & 0.00055 & 0.294 & 1.62297 & 0.007 & 0.005 & 0.016 & 0.004 & 0.003 & 1.766 & 5.018 \\
\hline Pakistan & 0.0008 & 0.001 & 0.002 & -0.0005 & 0.0009 & -0.2162 & 1.5098 & 0.007 & 0.005 & 0.0325 & 0.0025 & 0.0087 & 2.4979 & 7.5834 \\
\hline Philippines & -0.00018 & $-2.58 \mathrm{E}-05$ & 0.00031 & -0.00109 & 0.00039 & -1.1703 & 3.8282 & 0.00898 & 0.011 & 0.01683 & 0 & 0.00696 & -0.3412 & 1.4659 \\
\hline Qatar & 4.63E-05 & 0 & 0.00117 & -0.00118 & 0.00079 & -0.0097 & 1.928 & 0.00815 & 0.0096 & 0.0169 & 0 & 0.0066 & -0.1811 & 1.4426 \\
\hline Rfeder & 0.000652 & 0.00039 & 0.00363 & -0.00059 & 0.00118 & 1.64095 & 5.1812 & 0.014 & 0.0125 & 0.0299 & 0.0083 & 0.0061 & 1.7934 & 5.4594 \\
\hline Romania & 0.00025 & 0.00013 & 0.00085 & -0.0002 & 0.0003 & 0.5081 & 2.0386 & 0.00754 & 0.0075 & 0.0174 & 0 & 0.005 & 0.1461 & 2.9664 \\
\hline Africa & 0.00041 & 0.00044 & 0.00114 & -0.00039 & 0.00048 & -0.194 & 2.01 & 0.01106 & 0.0114 & 0.0169 & 0.007 & 0.0027 & 0.583 & 3.1408 \\
\hline Singapore & $-1.90 \mathrm{E}-05$ & $7.14 \mathrm{E}-05$ & 0.00059 & -0.00118 & 0.0004 & -1.4569 & 4.9926 & 0.0104 & 0.0107 & 0.013 & 0.0065 & 0.0021 & -0.41 & 2.0647 \\
\hline Srilanka & 0.0003 & 0.00017 & 0.0017 & -0.00061 & 0.0006 & 0.9166 & 3.676 & 0.009291 & 0.008918 & 0.012492 & 0.00626 & 0.002059 & 0.29668 & 2.1111 \\
\hline Thailand & 0.000567 & 0.00057 & 0.0021 & -0.00058 & 0.00088 & 0.3284 & 2.0865 & 0.00999 & 0.00881 & 0.01585 & 0.00406 & 0.00356 & 0.1806 & 2.205 \\
\hline Thailand & 0.00021 & 0.000287 & 0.000897 & -0.00049 & 0.000426 & -0.09576 & 2.0602 & 0.00986 & 0.00984 & 0.01474 & 0.00541 & 0.00293 & 0.23417 & 2.07917 \\
\hline Ukraine & 0.00036 & 0.00056 & 0.00282 & -0.00226 & 0.0019 & -0.1346 & 1.6083 & 0.0145 & 0.0156 & 0.0217 & 0.0028 & 0.00621 & -0.5594 & 2.1521 \\
\hline US & 0.0288 & 0.0002 & 0.2914 & -0.0042 & 0.0922 & 2.665 & 8.107 & 0.4686 & 0.0097 & 4.556 & 0 & 1.436 & 2.665 & 8.1084 \\
\hline Viet & $4.94 \mathrm{E}-05$ & 0 & 0.0016 & -0.0013 & 0.00072 & 0.5475 & 4.5585 & 0.004 & 0.003 & 0.013 & 0 & 0.005 & 0.3706 & 1.548 \\
\hline
\end{tabular}




\section{Correlation}

\begin{tabular}{|c|c|c|c|c|c|c|}
\hline & MR & CPI & GDP & IR & MCAP & UC \\
\hline MR & 1.000000 & & & & & \\
\hline CPI & 0.018285 & 1.000000 & & & & \\
\hline GDP & -0.045415 & 0.038964 & 1.000000 & & & \\
\hline IR & 0.050296 & -0.082369 & -0.134817 & 1.000000 & & \\
\hline MCAP & -0.027121 & -0.185139 & 0.018256 & -0.107450 & 1.000000 & \\
\hline UC & 0.983312 & 0.021376 & -0.046473 & $0.0523 \mathrm{q} 51$ & -0.024127 & 1.000000 \\
\hline
\end{tabular}

The correlation between the Consumer Price Index and Equity Market Indices shows a positive relationship with the coefficient value of 0.018285 indicates a very weak positive correlation between both of them. Similarly, Real Interest rates and Market Uncertainty has a positive relationship with the Market returns.

Then the GDP per capita growth and Market Capitalization has a weak negative correlation with the Market return with the value -0.045 and -0.027 respectively. 


\section{COUNTRY ANALYSIS:}

\begin{tabular}{|c|c|c|c|c|c|c|c|c|}
\hline Country & $\mathrm{C}$ & CPI & GDPPC & $\mathrm{UC}$ & $\mathrm{MC}$ & R.INT & R-Squared & DW Test \\
\hline Overall & $\begin{array}{l}0.004532 \\
(0.9482)\end{array}$ & $\begin{array}{l}-0.003702 \\
(0.7054)\end{array}$ & $\begin{array}{l}0.000306 \\
(0.9793)\end{array}$ & $\begin{array}{l}0.302568 \\
(0.0000)\end{array}$ & $\begin{array}{l}-4.21 \mathrm{E}-15 \\
(0.6615)\end{array}$ & $\begin{array}{l}-0.001106 \\
(0.8441)\end{array}$ & 0.966929 & 3.458441 \\
\hline Egypt & $\begin{array}{l}0.000435 \\
(0.9275)\end{array}$ & $\begin{array}{l}7.84 \mathrm{E}-05 \\
(0.6096)\end{array}$ & $\begin{array}{l}-2.86 \mathrm{E}-06 \\
(0.9969)\end{array}$ & $\begin{array}{l}3.07 \mathrm{E}-14 \\
(0.5480)\end{array}$ & $\begin{array}{l}-0.195929 \\
(0.3354)\end{array}$ & $\begin{array}{l}-3.92 \mathrm{E}-05 \\
(0.8576)\end{array}$ & 0.54712 & 2.565790 \\
\hline Nigeria & $\begin{array}{l}-0.00762 \\
(0.0768)\end{array}$ & $\begin{array}{l}0.000376 \\
(0.0850)\end{array}$ & $\begin{array}{l}-1.07 \mathrm{E}-05 \\
(0.9547)\end{array}$ & $\begin{array}{l}6.76 \mathrm{E}-05 \\
(0.4157)\end{array}$ & $\begin{array}{l}6.28 \mathrm{E}-14 \\
(0.0668)\end{array}$ & $\begin{array}{l}-0.024840 \\
(0.7630)\end{array}$ & 0.662155 & 2.023693 \\
\hline Bangladesh & 0.002055 & -0.635468 & -0.000822 & 0.001354 & $-7.09 \mathrm{E}-14$ & -0.000143 & N/A & 3.01266 \\
\hline India & $\begin{array}{l}-0.00388 \\
(0.6035)\end{array}$ & $\begin{array}{l}-9.57 \mathrm{E}-05 \\
(0.8504)\end{array}$ & $\begin{array}{l}0.000160 \\
(0.4072) \\
\end{array}$ & $\begin{array}{l}1.64 \mathrm{E}-15 \\
(0.3467)\end{array}$ & $\begin{array}{l}0.000172 \\
(0.5355) \\
\end{array}$ & $\begin{array}{l}0.044128 \\
(0.7753)\end{array}$ & 0.376180 & 2.391005 \\
\hline Pakistan & $\begin{array}{l}-0.00415 \\
(0.0780)\end{array}$ & $\begin{array}{l}0.061250 \\
(0.0650) \\
\end{array}$ & $\begin{array}{l}0.000878 \\
(0.1039) \\
\end{array}$ & $\begin{array}{l}0.000203 \\
(0.0468) \\
\end{array}$ & $\begin{array}{l}0.000369 \\
(0.0487) \\
\end{array}$ & $\begin{array}{l}-8.73 \mathrm{E}-15 \\
(0.6195) \\
\end{array}$ & 0.952263 & 3.222533 \\
\hline Indonesia & $\begin{array}{l}0.010401 \\
(0.0218)\end{array}$ & $\begin{array}{l}-0.000923 \\
(0.2071)\end{array}$ & $\begin{array}{l}-0.000414 \\
(0.1264)\end{array}$ & $\begin{array}{l}0.086802 \\
(0.3421)\end{array}$ & $\begin{array}{l}-0.000169 \\
(0.1973)\end{array}$ & $\begin{array}{l}-8.52 \mathrm{E}-15 \\
(0.0796)\end{array}$ & 0.807995 & 2.653436 \\
\hline Jordan & $\begin{array}{l}0.005451 \\
(0.7823)\end{array}$ & $\begin{array}{l}0.000957 \\
(0.5163)\end{array}$ & $\begin{array}{l}0.000438 \\
(0.3473)\end{array}$ & $\begin{array}{l}1.80 \mathrm{E}-05 \\
(0.9874)\end{array}$ & $\begin{array}{l}-0.006591 \\
(0.9724)\end{array}$ & $\begin{array}{l}-1.79 \mathrm{E}-13 \\
(0.7397)\end{array}$ & 0.554916 & 2.569217 \\
\hline Lebanon & $\begin{array}{l}-0.01310 \\
(0.0690)\end{array}$ & $\begin{array}{l}-0.000220 \\
(0.1356)\end{array}$ & $\begin{array}{l}0.000120 \\
(0.3111)\end{array}$ & $\begin{array}{l}0.070810 \\
(0.0000)\end{array}$ & $\begin{array}{l}1.18 \mathrm{E}-12 \\
(0.0691)\end{array}$ & $\begin{array}{l}-0.000203 \\
(0.1422)\end{array}$ & 0.999997 & $3.464188)$ \\
\hline Namibia & $\begin{array}{l}-0.00246 \\
(0.3613)\end{array}$ & $\begin{array}{l}5.98 \mathrm{E}-05 \\
(0.6289)\end{array}$ & $\begin{array}{l}0.000213 \\
(0.3434)\end{array}$ & $\begin{array}{l}-1.75 \mathrm{E}-05 \\
(0.8148)\end{array}$ & $\begin{array}{l}8.54 \mathrm{E}-13 \\
(0.3093)\end{array}$ & $\begin{array}{l}-0.020374 \\
(0.6669)\end{array}$ & 0.638108 & 3.003112 \\
\hline Oman & $\begin{array}{l}0.000249 \\
(0.8790)\end{array}$ & $\begin{array}{l}-6.02 \mathrm{E}-05 \\
(0.8455)\end{array}$ & $\begin{array}{l}0.000126 \\
(0.3263)\end{array}$ & $\begin{array}{l}0.071307 \\
(0.5932)\end{array}$ & $\begin{array}{l}-9.11 \mathrm{E}-15 \\
(0.8300)\end{array}$ & $\begin{array}{l}-1.23 \mathrm{E}-05 \\
0.7178)\end{array}$ & 0.460566 & 2.585287 \\
\hline Colombia & $\begin{array}{l}8.688608 \\
(0.6934)\end{array}$ & $\begin{array}{l}-0.959119 \\
(0.5875)\end{array}$ & $\begin{array}{l}-0.725652 \\
(0.6731)\end{array}$ & $\begin{array}{l}-0.816056 \\
(0.6754)\end{array}$ & $\begin{array}{l}0.308914 \\
(0.0016)\end{array}$ & $\begin{array}{l}1.38 \mathrm{E}-11 \\
(0.7878)\end{array}$ & 0.964464 & 2.834108 \\
\hline United states & $\begin{array}{l}-0.01093 \\
(0.3873)\end{array}$ & $\begin{array}{l}-0.000361 \\
(0.7787)\end{array}$ & $\begin{array}{l}0.000804 \\
(0.7295)\end{array}$ & $\begin{array}{l}0.064478 \\
(0.0000)\end{array}$ & $\begin{array}{l}0.003232 \\
(0.5419)\end{array}$ & $\begin{array}{l}1.28 \mathrm{E}-16 \\
(0.6931)\end{array}$ & 0.999421 & 2.338139 \\
\hline South Africa & $\begin{array}{l}0.003745 \\
(0.4852)\end{array}$ & $\begin{array}{l}-0.000535 \\
(0.2957)\end{array}$ & $\begin{array}{l}-0.000403 \\
(0.4304)\end{array}$ & $\begin{array}{l}-0.000567 \\
(0.2122)\end{array}$ & $\begin{array}{l}-0.034639 \\
(0.7758)\end{array}$ & $\begin{array}{l}1.49 \mathrm{E}-15 \\
(0.4743)\end{array}$ & 0.483358 & 1.662633 \\
\hline Ukraine & N/A & N/A & N/A & N/A & N/A & N/A & N/A & \\
\hline Thailand & $\begin{array}{l}0.005090 \\
(0.4960)\end{array}$ & $\begin{array}{l}3.11 \mathrm{E}-05 \\
(0.8934)\end{array}$ & $\begin{array}{l}-1.82 \mathrm{E}-05 \\
(0.9561) \\
\end{array}$ & $\begin{array}{l}-0.149441 \\
(0.6630) \\
\end{array}$ & $\begin{array}{l}-8.18 \mathrm{E}-15 \\
(0.4060)\end{array}$ & $\begin{array}{l}-1.62 \mathrm{E}-05 \\
(0.9693) \\
\end{array}$ & 0.303431 & 2.520305 \\
\hline Singapore & 0.001549 & 0.000130 & $-6.62 \mathrm{E}-05$ & -0.137335 & $-9.62 \mathrm{E}-16$ & $6.40 \mathrm{E}-05$ & 0.645524 & 1.810334 \\
\hline
\end{tabular}




\section{Macrothink $\underline{\text { Mnstitutem }}$}

Business and Economic Research

ISSN 2162-4860

2020, Vol. 10, No. 3

\begin{tabular}{|c|c|c|c|c|c|c|c|c|}
\hline & $(0.5608)$ & $(0.1788)$ & $(0.4749)$ & $(0.2428)$ & $(0.7513)$ & $(0.6722)$ & & \\
\hline Qatar & N/A & N/A & N/A & N/A & N/A & N/A & N/A & \\
\hline Romania & $\begin{array}{l}-0.00140 \\
(0.0490)\end{array}$ & $\begin{array}{l}0.000232 \\
(0.0452)\end{array}$ & $\begin{array}{l}9.24 \mathrm{E}-05 \\
(0.1273)\end{array}$ & $\begin{array}{l}0.000189 \\
(0.0259)\end{array}$ & $\begin{array}{l}-2.61 \mathrm{E}-14 \\
(0.3491)\end{array}$ & $\begin{array}{l}-0.035314 \\
(0.2423)\end{array}$ & 0.797795 & 2.109276 \\
\hline Philippines & $\begin{array}{l}0.001172 \\
(0.6469)\end{array}$ & $\begin{array}{l}-2.88 \mathrm{E}-05 \\
(0.8403)\end{array}$ & $\begin{array}{l}-0.046669 \\
(0.2373)\end{array}$ & $\begin{array}{l}-6.59 \mathrm{E}-05 \\
(0.8028)\end{array}$ & $\begin{array}{l}-0.000205 \\
(0.4113)\end{array}$ & $\begin{array}{l}3.42 \mathrm{E}-16 \\
(0.9448)\end{array}$ & 0.445161 & 2.121354 \\
\hline New Zealand & $\begin{array}{l}-0.00114 \\
(0.5728)\end{array}$ & $\begin{array}{l}0.000410 \\
(0.5089)\end{array}$ & $\begin{array}{l}4.96 \mathrm{E}-05 \\
0.7612)\end{array}$ & $\begin{array}{l}-6.94 \mathrm{E}-05 \\
(0.5159)\end{array}$ & $\begin{array}{l}\text { 1.74E-14 } \\
(0.3580)\end{array}$ & $\begin{array}{l}-0.052262 \\
(0,0898)\end{array}$ & 0.996383 & 2.946723 \\
\hline Mexico & $\begin{array}{l}0.000403 \\
(0.7127)\end{array}$ & $\begin{array}{l}-4.96 \mathrm{E}-05 \\
(0.3676)\end{array}$ & $\begin{array}{l}-5.43 \mathrm{E}-16 \\
(0.7761)\end{array}$ & $\begin{array}{l}0.000581 \\
(0.9681)\end{array}$ & $\begin{array}{l}-3.15 \mathrm{E}-05 \\
(0.7656)\end{array}$ & $\begin{array}{l}\text { 6.07E-05 } \\
(0.5754)\end{array}$ & 0.468316 & 1.517463 \\
\hline Sri lanka & $\begin{array}{l}0.004734 \\
(0.0097)\end{array}$ & $\begin{array}{l}1.68 \mathrm{E}-05 \\
(0.6800)\end{array}$ & $\begin{array}{l}-4.50 \mathrm{E}-05 \\
(0.0762)\end{array}$ & $\begin{array}{l}-0.000118 \\
(0.0840)\end{array}$ & $\begin{array}{l}-1.63 \mathrm{E}-13 \\
(0.0060)\end{array}$ & $\begin{array}{l}-0.061233 \\
(0.2542)\end{array}$ & 0.950247 & 2.390514 \\
\hline Kenya & $\begin{array}{l}-0.00057 \\
(0.8800)\end{array}$ & $\begin{array}{l}-0.000158 \\
(0.7788)\end{array}$ & $\begin{array}{l}3.13 \mathrm{E}-05 \\
(0.9044)\end{array}$ & $\begin{array}{l}0.091667 \\
(0.2033)\end{array}$ & $\begin{array}{l}2.68 \mathrm{E}-05 \\
(0.9157)\end{array}$ & $\begin{array}{l}5.39 \mathrm{E}-14 \\
(0.6801)\end{array}$ & 0.615754 & 1.734483 \\
\hline Japan & $\begin{array}{l}0.000701 \\
(0.8917)\end{array}$ & $\begin{array}{l}-8.03 E-05 \\
(0.7068)\end{array}$ & $\begin{array}{l}-0.029036 \\
(0.8674)\end{array}$ & $\begin{array}{l}-0.000126 \\
(0.8405)\end{array}$ & $\begin{array}{l}-0.000155 \\
(0.8260)\end{array}$ & $\begin{array}{l}1.12 \mathrm{E}-16 \\
(0.8717)\end{array}$ & 0.139723 & 1.766646 \\
\hline Jordan & $\begin{array}{l}-0.00259 \\
(0.4962)\end{array}$ & $\begin{array}{l}-0.000353 \\
(0.2991)\end{array}$ & $\begin{array}{l}5.15 \mathrm{E}-05 \\
(0.5980)\end{array}$ & $\begin{array}{l}-0.042932 \\
(0.3744)\end{array}$ & $\begin{array}{l}0.000274 \\
(0.2815)\end{array}$ & $\begin{array}{l}3.06 \mathrm{E}-14 \\
(0.7536)\end{array}$ & 0.389701 & 2.851114 \\
\hline Hungary & $\begin{array}{l}0.002081 \\
(0.6411)\end{array}$ & $\begin{array}{l}-0.000131 \\
(0.5850) \\
\end{array}$ & $\begin{array}{l}-0.000187 \\
(0.5651) \\
\end{array}$ & $\begin{array}{l}-0.000115 \\
(0.7378)\end{array}$ & $\begin{array}{l}-2.31 \mathrm{E}-14 \\
(0.8786)\end{array}$ & $\begin{array}{l}-0.033170 \\
(0.7475)\end{array}$ & 0.392185 & 2.346545 \\
\hline Thailand & $\begin{array}{l}0.003914 \\
(0.2798)\end{array}$ & $\begin{array}{l}6.78 \mathrm{E}-06 \\
(0.9371)\end{array}$ & $\begin{array}{l}-0.132895 \\
(0.3906)\end{array}$ & $\begin{array}{l}-0.000126 \\
(0.5768)\end{array}$ & $\begin{array}{l}-0.000167 \\
(0.3481)\end{array}$ & $\begin{array}{l}-4.90 \mathrm{E}-15 \\
(0.2355)\end{array}$ & 0.390637 & 2.189068 \\
\hline China & $\begin{array}{l}-0.01515 \\
(0.0667)\end{array}$ & $\begin{array}{l}0.000995 \\
(0.0711)\end{array}$ & $\begin{array}{l}-0.022573 \\
(0.7064)\end{array}$ & $\begin{array}{l}0.000719 \\
(0.0662)\end{array}$ & $\begin{array}{l}0.000770 \\
(0.1042)\end{array}$ & $\begin{array}{l}8.49 \mathrm{E}-16 \\
(0.1268)\end{array}$ & 0.725633 & 2.465462 \\
\hline Chile & $\begin{array}{l}0.002346 \\
(0.1373)\end{array}$ & $\begin{array}{l}-0.000132 \\
(0.2471)\end{array}$ & $\begin{array}{l}-0.050258 \\
(0.6832)\end{array}$ & $\begin{array}{l}-0.000117 \\
(0.1696)\end{array}$ & $\begin{array}{l}-0.000117 \\
(0.4069)\end{array}$ & $\begin{array}{l}-0.000191 \\
(0.5820)\end{array}$ & 0.715817 & 2.462466 \\
\hline Canada & $\begin{array}{l}0.000209 \\
(0.9797)\end{array}$ & $\begin{array}{l}-0.000417 \\
(0.4705)\end{array}$ & $\begin{array}{l}-0.012344 \\
(0.9462)\end{array}$ & $\begin{array}{l}-0.000330 \\
(0.6106)\end{array}$ & $\begin{array}{l}-0.000292 \\
(0.5576)\end{array}$ & $\begin{array}{l}\text { 7.04E-16 } \\
(0.7970)\end{array}$ & 0.834507 & 2.578567 \\
\hline Brazil & $\begin{array}{l}-0.00314 \\
(0.0810)\end{array}$ & $\begin{array}{l}-0.000293 \\
(0.1239)\end{array}$ & $\begin{array}{l}-0.050813 \\
(0.6889)\end{array}$ & $\begin{array}{l}2.13 \mathrm{E}-05 \\
(0.4923)\end{array}$ & $\begin{array}{l}-7.43 \mathrm{E}-05 \\
(0.5226)\end{array}$ & $\begin{array}{l}3.85 \mathrm{E}-15 \\
(0.0389)\end{array}$ & 0.866878 & 1.975917 \\
\hline Hong Kong & $\begin{array}{l}-0.00110 \\
(0.7412)\end{array}$ & $\begin{array}{l}-6.87 \mathrm{E}-05 \\
(0.5641)\end{array}$ & $\begin{array}{l}-0.070155 \\
(0.3930)\end{array}$ & $\begin{array}{l}0.000177 \\
(0.5373)\end{array}$ & $\begin{array}{l}-6.50 \mathrm{E}-05 \\
(0.8588)\end{array}$ & $\begin{array}{l}5.48 \mathrm{E}-16 \\
(0.3568)\end{array}$ & 0.470037 & 1.913022 \\
\hline Bulgaria & $\begin{array}{l}-0.00038 \\
(0.9310)\end{array}$ & $\begin{array}{l}8.21 \mathrm{E}-05 \\
(0.8912)\end{array}$ & $\begin{array}{l}0.037683 \\
(0.6226)\end{array}$ & $\begin{array}{l}0.000241 \\
(0.7216)\end{array}$ & $\begin{array}{l}-6.75 \mathrm{E}-05 \\
(0.8686)\end{array}$ & $\begin{array}{l}6.99 \mathrm{E}-14 \\
(0.8367)\end{array}$ & 0.199986 & 2.546986 \\
\hline Australia & $\begin{array}{l}-0.00264 \\
(0.4939)\end{array}$ & $\begin{array}{l}-0.000115 \\
(0.7730)\end{array}$ & $\begin{array}{l}0.085582 \\
(0.4590)\end{array}$ & $\begin{array}{l}-6.91 \mathrm{E}-06 \\
(0.9379)\end{array}$ & $\begin{array}{l}-0.000491 \\
(0.1499)\end{array}$ & $\begin{array}{l}2.48 \mathrm{E}-15 \\
(0.2991)\end{array}$ & 0.529822 & 1.285875 \\
\hline
\end{tabular}




\begin{tabular}{|l|l|l|l|l|l|l|l|l|}
\hline Croatia & N/A & N/A & N/A & N/A & N/A & N/A & N/A & \\
\hline Korea, Rep. & $\begin{array}{l}-0.00095 \\
(0.5630)\end{array}$ & $\begin{array}{l}-9.02 \mathrm{E}-05 \\
(0.5838)\end{array}$ & $\begin{array}{l}-0.055997 \\
(0.2943)\end{array}$ & $\begin{array}{l}-5.55 \mathrm{E}-05 \\
(0.7978)\end{array}$ & $\begin{array}{l}5.27 \mathrm{E}-05 \\
(0.8363)\end{array}$ & $\begin{array}{l}1.31 \mathrm{E}-15 \\
(0.2612)\end{array}$ & 0.547096 & 1.603997 \\
\hline Mauritius & $\begin{array}{l}0.003932 \\
(0.4213)\end{array}$ & $\begin{array}{l}-0.000432 \\
(0.5633)\end{array}$ & $\begin{array}{l}-0.087606 \\
(0.3439)\end{array}$ & $\begin{array}{l}-4.21 \mathrm{E}-05 \\
(0.8428)\end{array}$ & $\begin{array}{l}-0.000246 \\
(0.4732)\end{array}$ & $\begin{array}{l}6.94 \mathrm{E}-15 \\
(0.9783)\end{array}$ & 0.401501 & 2.315593 \\
\hline \multirow{2}{*}{ Namibia } & $\begin{array}{l}-0.00891 \\
(0.1398)\end{array}$ & $\begin{array}{l}0.000638 \\
(0.0572)\end{array}$ & $\begin{array}{l}0.572940 \\
(0.0061)\end{array}$ & $\begin{array}{l}0.000840 \\
(0.1165)\end{array}$ & $\begin{array}{l}-2.86 \mathrm{E}-05 \\
(0.8289)\end{array}$ & $\begin{array}{l}3.11 \mathrm{E}-14 \\
(0.9742)\end{array}$ & 0.890028 & 1.548920 \\
\hline Russian Federation & $\begin{array}{l}-0.00245 \\
(0.1772)\end{array}$ & $\begin{array}{l}0.116174 \\
(0.4927)\end{array}$ & $\begin{array}{l}4.20 \mathrm{E}-05 \\
(0.9255)\end{array}$ & $\begin{array}{l}0.000114 \\
(0.4141)\end{array}$ & $\begin{array}{l}2.43 \mathrm{E}-05 \\
(0.7688)\end{array}$ & $\begin{array}{l}1.47 \mathrm{E}-15 \\
(0.6481)\end{array}$ & 0.876729 & 1.737559 \\
\hline Vietnam & $\begin{array}{l}-0.00240 \\
(0.6168)\end{array}$ & $\begin{array}{l}0.000537 \\
(0.4108)\end{array}$ & $\begin{array}{l}-0.173671 \\
(0.0583)\end{array}$ & $\begin{array}{l}-5.33 \mathrm{E}-05 \\
(0.7862)\end{array}$ & $\begin{array}{l}1.35 \mathrm{E}-05 \\
(0.9643)\end{array}$ & $\begin{array}{l}1.42 \mathrm{E}-14 \\
(0.2393)\end{array}$ & 0.722830 & 1.861218 \\
\hline
\end{tabular}

* This table presents the regression model results linking the financial market returns with the Financial Market Uncertainty (UC) along with the macro-economic variables like Consumer Price Index (CPI), Gross Domestic Product per capita growth (GDPPCG), Market Capitalization (MC) and Real Interest rates (R.INT).

Coefficients are displayed along with $\mathrm{p}$ values in bracket

A rule of thumb for DW test is that, statistics value between the ranges of 1.5 to 2.5 are relatively normal. There is no auto correlation (serial relationship) if the value is 2 and if the value is greater than 2 and ranges in 2 to 4 indicates a negative auto correlation and the value ranges 0 to 2 indicates a positive auto correlation between the samples

EGYPT: All the variables have p-value greater than 0.05 which means they are insignificant in explaining market returns including that all the variables have negative relationship with the market return except financial market uncertainty and consumer price index because when the Egyptian revolution occur it may cause increase in CPI and Uncertainty which ultimately impact market returns.

NIGERIA: All the variables are significant except GDP per capita growth and Real Interest rates and all have positive relationship with market return except these two variables which are insignificant.

BANGLADESH: All the variables have negative relationship with the market returns except financial market uncertainty so, when the market the face volatility with the same proportion market returns move with the same direction.

INDIA: All the variables are insignificant while the model has strength of only $37 \%$ in India and Durbin Watson shows negative auto correlation between the variables.

PAKISTAN: Model showing the strength of $95 \%$ in Pakistan and all the variables have positive relationship except Market Capitalization. While Real Interest rates and GDP per capita are insignificant because according to the results there is no major impact of these two variables on market returns in Pakistan. 


\section{Macrothink}

INDONESIA: All the variables are insignificant except Market Capitalization and all have negative relationship with market return except Financial Market Uncertainty with the $80 \%$ overall strength of the model and due the disturbance in the economy caused after the earthquakes are major reason of high volatilities in Indonesia.

JORDAN: All the variables are insignificant while the model is 55\% strong and all the variables have positive relationship except Market capitalization and Real Interest rates.

LEBANON: Only two variables are significant in this model Market capitalization and Financial Market Uncertainty while all the factors have positive relationship except Real Interest rates and Consumer Price Index.

NAMIBIA: Regression results shows $63 \%$ overall strength of the model and showing all the variables have insignificant relation with the market return and only Financial Market Uncertainty and Real Interest have negative relation with the market return.

OMAN: All the variables are insignificant because all have p value more than 0.05 and model shows $46 \%$ strength in the Oman while Financial Market Uncertainty and GDP per capita growth have positive relation with the market return.

COLOMBIA: All the variables have p-value more than 0.05 except Market Capitalization and overall strength of the model in Colombia is around $96 \%$ and all the variables have negative relationship except Market Capitalization and Real Interest rates which means when performance of the economy high market returns are also high.

UNITED STATES: All the variables have positive relationship with the market return except Consumer Price Index which means when the rate of CPI increase in US it would negatively affect its market returns. Only Financial Market Uncertainty have significant value in this model.

SOUTH AFRICA: In South Africa, this model is showing 48\% strength while all the variables are insignificant and all have negative relationship with the market return except market capitalization.

UKRAINE: Due to the unavailability of some factors data for selected time period, regression test is giving an error.

THAILAND: All the variables have insignificant relationship, while model have only $30 \%$ strength and all the variables have negative relationship except Consumer Price Index.

SINGAPORE: All the variables have $\mathrm{p}$ value more than the 0.05 which means all are insignificant and regression showing $64 \%$ strength of the model. All variables have negative relation except Consumer Price Index and Real Interest rates.

QATAR: Due to the unavailability of some factors data for selected time period, regression test is giving an error.

ROMANIA: The regression results showed 79\% overall strength of the model and all the variables are insignificant except Consumer Price Index and Financial Market Uncertainty. Other than this Market Capitalization and Real interest rates have negative relation with market return. 


\section{Macrothink}

Business and Economic Research

ISSN 2162-4860

PHILIPPINES: Overall strength of the model is $44 \%$ and all the variables are insignificant while all have negative relationship with the market return except Real Interest rates.

NEW ZEALAND: All the variables are insignificant except Real Interest rates and all the variables have positive relationship except Financial Market Uncertainty and Real Interest rates.

MEXICO: All the variables are insignificant because all have p value more than 0.05 and overall strength of the model is $46 \%$ and all the variables have negative relation except Financial Market Uncertainty and Real Interest Rates.

SRI LANKA: All the variables have negative relation with the market return except Consumer Price Index and all the variables are significant except Consumer Price Index and Real Interest rates.

KENYA: Model showing 61\% overall strength and all the variables have positive relation with the market return except Consumer Price Index and all the variables are insignificant.

JAPAN: In japan model showing only $13 \%$ strength which is too weak means other factors are more contributing to analyze market return and all the variables are insignificant and all have negative relationship except Real Interest rates.

HUNGARY: All the variables have insignificant relationship and all have negative relationship. While regression shows only 39\% overall strength of the model.

CHINA: Overall strength of the model is $72 \%$ while all the variables are insignificant because all have values more than 0.05 except Consumer Price Index and Financial Market Uncertainty. All the variables have positive relation with market return except GDP per capita growth.

CHILE: All the variables have negative relationship while model has $71 \%$ overall strength and all the variables are insignificant and Durbin Watson value is 2.46 which means all the variables have negative auto correlation.

CANADA: All the variables have insignificant relationship and all have negative relationship except Financial Market Uncertainty. While regression shows $83 \%$ overall strength of the model and Durbin Watson value is 2.57 which means all the variables have negative auto correlation.

BRAZIL: Durbin Watson value is 1.97 which means all the variables have positive auto correlation. All the variables are insignificant because all have values more than 0.05 except Real Interest rates and all have negative relation except Financial Market Uncertainty and Real Interest rates.

HONG KONG: All the variables have negative relation except Financial Market Uncertainty and Real Interest rates and all are insignificant. Model showing the overall strength of $47 \%$ and DW value is 1.91 which means positive auto correlation exist.

BULGARIA: All the variables are insignificant and model just have $19 \%$ overall strength and all the variables have positive relation except 
Market Capitalization.

AUSTRALIA: All are insignificant and model have 52\% overall strength. All the variables have negative relation except GDP per capita growth and Real Interest rates and DW value is 1.28 which means positive auto correlation exist.

CROATIA: Due to the unavailability of some factors data for selected time period, regression test is giving an error.

KOREA, REP: Overall strength of the model is $54 \%$ while all the variables are insignificant because all have values more than 0.05 . All the variables have positive relation with market return except Real Interest rates and DW value is 0.54 which means positive auto correlation exist.

MAURITIUS: All the variables are insignificant because all have p value more than 0.05 and overall strength of the model is $40 \%$ and all the variables have negative relation except Real Interest Rates.

NAMIBIA: Overall model is $89 \%$ strong while all the variables are insignificant except Consumer Price Index and GDP per capita growth. All the variables have positive relation except Market Capitalization and DW value is 1.73 which means positive auto correlation exist.

RUSSIAN FEDERATION: Overall strength of the model is $87 \%$ while all the variables are insignificant because all have values more than 0.05 . All the variables have positive relation with market return and DW value is 1.73 which means positive auto correlation exist.

VIETNAM: All the variables have insignificant relationship and all have negative relationship except Real Interest rates and Market Capitalization. While regression shows $72 \%$ overall strength of the model and Durbin Watson value is 1.86 which means all the variables have positive auto correlation.

OVERALL: In this model Market uncertainty is the significant variable because its probability value is less than 0.05 but the other variables Consumer Price Index, GDP per capita growth, Real Interest rates, Market Capitalization has values 0.7054, 0.9793, 0.8441 and 0.6615 which is more than 0.05 which means they are the insignificant variables for explaining Equity Market Indices.

The negative coefficient values of CPI consumer price index which is -0.003 means that when the CPI goes down Equity Market indices return will goes up and vice versa. Similarly with Real interest rates and Market capitalization with the value of -0.001 and -4.21 it also follows the same inverse relationship with the Equity market indices return. But GDP per capita growth and Market Uncertainty has a positive relationship with the value 0.0003 and 0.35268 with dependent variable it means that when the GDP per capita growth and Market Uncertainty increases with the same proportion, returns will also increases.

The value of R-squared showed around 96\% of variation on Equity Market Indices (dependent variable) of different countries is enlightened by the variation in macroeconomic factors ( Market Uncertainty, Consumer Price Index, Real Interest Rates, Gross Domestic Product per capita growth). The results shows DW stats having a value of 3.458441, which indicates a negative autocorrelation between the samples 


\section{Discussion}

Around 23 countries out of 40 showing regression value more than $50 \%$ strength of the model, which means in most of the countries the selected independent variables are defining the dependent variable.

The countries which have below 50\% (R-square) value are some of developing countries like India, South Africa, Oman, Thailand, and Philippines except developed countries like Japan, Jordan, Hong Kong, Hungary, Bulgaria, and Mauritius so, we can't create a link of the impact of financial market uncertainty on market returns regarding the developing or developed nations. We can take the example of Singapore which is the ninth most developed nation of the world and having a most competitive economy in the world and according to the latest information having world's highest GDP rate of $7.7 \%$ and its R-squared value is $64 \%$ other than this Pakistan which is newly entered into the emerging market have R-square value around $95 \%$ and the middle class is growing promptly, getting into the tens of millions.

The first influential factor is Financial Market Uncertainty in which around half countries out of 40 have a negative relationship with the market returns and the same finding is found in the article, in which 7 countries out of 10 have a negative impact of Financial Market Uncertainty on both stocks and bonds in the long run (Nebojsa Dimic, Jarno Kiviaho, Vanja Piljak*, Janne Äij0, 2016). Consumer Price Index which mostly negative correlation co-efficient values showing negative relation of Consumer Price Index with the Market returns. Similarly, in many other studies, we found a negative relationship of the Consumer Price Index with the market returns (D. V. Lokeswar Reddy, 2012 Azar, 2014 and Osagie \& Emeni, 2015).

Similarly, Gross Domestic Product per capita growth and Market capitalization have a negative relationship with the Market returns because more than half of the countries have a negative value of correlation co-efficient which describes that when the Gross Domestic Product per capita growth and Market Capitalization is increased it ultimately cause declines in market returns and this result is supported by previous studies as well. Laichena and Obwogi (2015) research to explore this relationship and findings were the same.

In last, Real Interest rates have a positive relationship with the Market returns because around 25 countries have a positive correlation coefficient values. So, when the interest rates rise it would give increase in Market returns. D. V. Lokeswar Reddy (2012) conduct the research and their results were the same when the interest rates increase it ultimately gives a positive impact on Market returns.

\section{Conclusion}

The methodology applies on the panel data of multiple countries of the same data of ten years. The correlation is the first objective of the study that has been analyzed in a way that each component's relation and significance is viewed with the explained variable. The results that has been generated is also viewed with the help of Regression i.e., the second objective of the study on a single basis and then overall impact is viewed of different macro components on 
the performance of the Equity market. The model summary shows the overall strength of the variables that may help in bringing on board any underlying impact, and helped us in a single view to observe the impact of each macro factor on the overall performance of the Equity Market.

By studying the ten years impact of financial market uncertainty in this study researchers can be able to understand the market fluctuations and the impact of crises diverge across the time frequencies and it also facilitates the policymakers regarding the macro-economic policies that continuously monitor and adjust the market according to the trends. This research is also helpful for the new researchers to emphasize on the different methods for measuring Market Uncertainties which discussed in this research and can also use the described method for the future analysis and calculation of upcoming Market uncertainties in future.

It is concluded that Financial Market uncertainty has a significant impact on the Market returns and this phenomenon is appropriate in all over the countries so during the crises Financial Market uncertainties move upwards along this Market returns also moved with the same proportion. Other than this, macro-economic variables also have a significant impact on the market returns.

So, the overall significance of the research paper is that it will be helpful for the upcoming researchers and serve as a base paper and this technique can be used further for exploring upcoming volatilities in the different stock markets of the world. It is helpful in taking experience from previous occurred events that how the market reacts at the time of crises like in this paper we study about Canada that its volatility rate is high in 2009 because at that time its economy was entered into the Recession phase due to rise in interest rates consumer expenditures and business investment decreased sharply and at that time government was too late to take measureable actions to overcome this problem like decrease in interest rates and increase in the money supply. Similarly, many other situations of different countries discussed in this paper which would be helpful to overcome if a similar type of problem will occur in the future.

\section{Acknowledgement}

First of all, I would like to thanks my parents for their tremendous support and would also like to express gratitude towards our research facilitator Dr. Danish Ahmed Siddique for guiding, helping, and providing us with the opportunity that makes us able to produce this research report as a part of our MBA thesis requirement with utmost patience and cooperation. We find this research paper to be truly challenging in many aspects, indeed very interesting about to the interpretational exercises. We have tried our level best to complete the research paper concerning for the desired requirements. However, if any explanation is required, we would be honoured to oblige. In the end, we would like to thanks our families, the faculty of Karachi University Business School who has always uplifted us through their moral, professional, and technical support. We hope that this research paper will merit your approval. 


\section{References}

Ariss, R. T. (2012). Understanding Inflation and Revising National Price Data Lebanese Economic Association, Beirut-Lebanon

Arouri, M., Estay, C., Rault, C., \& Roubaud, D. (2016). Economic policy uncertainty and stock markets: Long-run evidence from the US. Finance Research Letters, 18, 136-141. https://doi.org/10.1016/j.frl.2016.04.011

Azar, S. A. (2014). Inflation and stock returns II. International Journal of Economics and Finance, 6(1), 208-216. http://dx.doi.org/10.5539/ijef.v6n1p208

Bachmann, R., Elstner, S., \& Sims, E. R. (2013). Uncertainty and economic activity: Evidence from business survey data. American Economic Journal: Macroeconomics, 5(2), 217-49. http://dx.doi.org/10.1257/mac.5.2.217

Badshah, I. U., Frijns, B., \& Tourani-Rad, A. (2013). Contemporaneous spill-over among equity, gold, and exchange rate Implied Volatility Indices. Journal of Futures Markets, 33(6), 555-572. https://doi.org/10.1002/fut.21600

Bessembinder, H., Chan, K., Seguin, P. J. (1996). An empirical examination of information, differences of opinion, and trading activity. Journal of Financial Economics, 40, 105-134. https://doi.org/10.1016/0304-405X(95)00839-7

Bikhchandani, S., Hirshleifer, D., \& Welch, I. (1992). A theory of fads, fashion, custom, and cultural change as informational cascades. Journal of Political Economy, 100, 992-1026. https://doi.org/10.1086/261849

Boldanov, R., Degiannakis, S., \& Filis, G. (2016). Time-varying correlation between oil and stock market volatilities: Evidence from oil-importing and oil-exporting countries. International Review of Financial Analysis, 48, 209-220.

https://doi.org/10.1016/j.irfa.2016.10.002

Bomfim, A. N. (2003). Pre-announcement effects, news, and volatility: monetary policy and the stock market. Journal of Banking and Finance, 27(1), 133-151.

https://doi.org/10.1016/S0378-4266(01)00211-4

Bulkley, G., \& Harris, R. D. (1997). Irrational analysts' expectations as a cause of excess volatility in stock prices. The Economic Journal, 107(441), 359-371.

https://doi.org/10.1111/j.0013-0133.1997.163.x

Carlstrom, C. T., Fuerst, T. S., \& Ioannidou, V. P. (2002). Stock prices and output growth: an examination of the credit channel. Federal Reserve Bank of Cleveland. [Online] Available: https://core.ac.uk/download/pdf/6893289.pdf

Chang, E. C., Cheng, J. W., \& Khorana, A. (2000). An examination of herd behavior in equity markets: An international perspective. Journal of Banking and Finance, 24(10), 1651-1679. https://doi.org/10.1016/S0378-4266(99)00096-5

Chen, S. J., \& Jordan, B. D. (1993). Some empirical tests in the arbitrage pricing theory: 
Macro variables vs. derived factors. Journal of Banking \& Finance, 17(1), 65-89. https://doi.org/10.1016/0378-4266(93)90080-W

Christie, W. G., \& Huang, R. D. (1995). Following the pied piper: Do individual returns herd around the market?. Financial Analysts Journal, July-August, 31-37.

https://doi.org/10.2469/faj.v51.n4.1918

Chuliá, H., Martens, M., \& Van Dijk, D. (2010). Asymmetric effects of federal funds target rate changes on s\&p stock returns, volatilities and correlations. Journal of Banking and Finance, 34, 834-839. https://doi.org/10.17015/ejbe.2015.015.09

Connolly, R., \& Stivers, C. (1998). Conditional stock market return autocorrelation and price formation: evidence from six major equity markets. Working paper, University of Georgia and University of North Carolina at Chapel Hill.

Connolly, R., Stivers, C., \& Sun, L. (2005). Stock market uncertainty and the stock-bond return relation. Journal of Financial and Quantitative Analysis, 40(1), 161-194. [Online] Available: https://www.jstor.org/stable/27647190

Degiannakis, S., Filis, G., \& Kizys, R. (2014). The effects of oil price shocks on stock market volatility: Evidence from European data. The Energy Journal, 35(1).

https://doi.org/10.5547/01956574.35.1.3

Devenow, A., \& Welch, I. (1996). Rational herding in financial economics. European Economic Review, 40, 603-615. https://doi.org/10.1016/0014-2921(95)00073-9

Dick, C. D., Schmeling, M., \& Schrimpf, A. (2013). Macro-expectations, aggregate uncertainty, and expected term premia. European Economic Review, 58, 58-80.

https://doi.org/10.1016/j.euroecorev.2012.11.005

Dimic, N., Kiviaho, J., Piljak, V., \& Äijö, J. (2016). Impact of financial market uncertainty and macroeconomic factors on stock-bond correlation in emerging markets. Research in International Business and Finance, 36, 41-51. https://doi.org/10.1016/j.ribaf.2015.09.001

Engle, R. (2002). Dynamic conditional correlation: A simple class of multivariate generalized autoregressive conditional heteroskedasticity models. Journal of Business \& Economic Statistics, 20(3), 339-350. https://doi.org/10.1198/073500102288618487

Evbayiro-Osagie, E. I., \& Emeni, F. K. (2015). INFLATION RATES, FINANCIAL OPENNESS, EXCHANGE RATES AND STOCK MARKET RETURNS VOLATILITY IN NIGERIA. Ican Journal Of Accounting \& Finance, 4(1), 125-140. [Online] Available:

http://eprints.covenantuniversity.edu.ng/id/eprint/5602

Fair, R. C. (2002). Events that shook the market. Journal of Business, 75, 713-731. https://doi.org/10.1086/341640

Fama, E. F. (1991). Efficient capital markets: II. The Journal of Finance, 46, 1575-1617. https://doi.org/10.1111/j.1540-6261.1991.tb04636.x

French, K. R., Schwert, G. S., \& Stambaugh, R. F. (1987). Expected stock returns and 
volatility. Journal of Financial Economics, 19,-30.

https://doi.org/10.1016/0304-405X(87)90026-2

Geetha, C., Mohidin, R., Chandran, V. V., \& Chong, V. (2011). The relationship between inflation and stock market: Evidence from Malaysia, United States and China. International journal of economics and management sciences, 1(2), 1-16. [Online] Available:

http://free-journal.umm.ac.id/files/file/the-relationship-between-inflation-and-stock-market-e vidence-from-malaysia-united-states-and-china-2162-6359-1-011.pdf

Geske, R., \& Roll, R. (1983). The fiscal and monetary linkage between stock returns and inflation. The journal of Finance, 38(1), 1-33.

https://doi.org/10.1111/j.1540-6261.1983.tb03623.x

Gupta, R., Lau, C. K. M., \& Wohar, M. E. (2019). The impact of US uncertainty on the Euro area in good and bad times: evidence from a quantile structural vector autoregressive model. Empirica, 46(2), 353-368. https://doi.org/10.1007/s10663-018-9400-3

Hoque, M. E., \& Zaidi, A. S. (2019). IMPACTS OF GLOBAL ECONOMIC POLICY UNCERTAINTY ON EMERGING STOCK MARKETS: EVIDENCE FROM LINEAR AND NON-LINEAR MODELS. Prague Economic Papers, 1-12. https://doi.org/10.18267/j.pep.725 https://fred.stlouisfed.org/series/ for World Uncertainty Index

https://www.investing.com/ for daily market returns

Jones, P. M., \& Olson, E. (2013). The time-varying correlation between uncertainty, output, and inflation: Evidence from a DCC-GARCH model. Economics Letters, 118(1), 33-37. https://doi.org/10.1016/j.econlet.2012.09.012

Jubinski, D., \& Lipton, A. F. (2013). VIX, gold, silver, and oil: how do commodities react to financial market volatility?. Journal of Accounting and Finance, 13(1), 70-88. [Online] Available: http://www.na-businesspress.com/JAF/jubinski_abstract.html

Kang, W., Lee, K., \& Ratti, R. A. (2014). Economic policy uncertainty and firm-level investment. Journal of Macroeconomics, 39, 42-53.

https://doi.org/10.1016/j.jmacro.2013.10.006

Laichena, K. E., \& Obwogi, T. N. (2015). Effects of macroeconomic variables on stock returns in the East African community stock exchange market. International journal of education and research, 3(10), 305-320. [Online] Available:

http://www.ijern.com/journal/2015/October-2015/24.pdf

Latanè, H. A., \& Rendleman, R. J. (1976). Standard Deviations of Stock Price Ratios Implied in Options Prices. Journal of Finance, 31(1976), 369-381.

https://doi.org/10.1111/j.1540-6261.1976.tb01892.x

Lin, F. L., Yang, S. Y., Marsh, T., \& Chen, Y. F. (2018). Stock and bond return relations and stock market uncertainty: Evidence from wavelet analysis. International Review of Economics \& Finance, 55, 285-294. https://doi.org/10.1016/j.iref.2017.07.013 


\section{$\triangle 1$ Macrothink}

Business and Economic Research ISSN 2162-4860 2020, Vol. 10, No. 3

Liu, X., Margaritis, D., \& Wang, P. (2012). Stock market volatility and equity returns: Evidence from a two-state Markov-switching model with regressors. Journal of Empirical Finance, 19(4), 483-496. https://doi.org/10.1016/j.jempfin.2012.04.011

Mohan, C., \& Chitradevi, N. (2014). Impact of inflation and exchange rate on stock market performance in India. Indian Journal of Applied Research, 4(3), 230-232. https://doi.org/10.15373/2249555X/MAR2014/69

Nikkinen, J., \& Sahlström, P. (2004). Impact of the federal open market committee's meetings and scheduled macroeconomic news on stock market uncertainty. International Review of Financial Analysis, 13(1), 1-12. https://doi.org/10.1016/j.irfa.2004.01.001

Rajan, R. G. (1994). Why credit policies Fluctuate: A theory and some evidence. Quarterly Journal of Economics, 436, 399-442. https://doi.org/10.2307/2118468

Rapach, D. E., Strauss, J. K., \& Zhou, G. (2013). International stock return predictability: what is the role of the United States?. The Journal of Finance, 68(4), 1633-1662. https://doi.org/10.1111/jofi.12041

Reddy, D. L. (2012). Impact of inflation and GDP on stock market returns in India. International Journal of Advanced Research in Management and Social Sciences, 1(6), 120-136. http://garph.co.uk/IJARMSS/Dec2012/9.pdf

Reinganum, M. R. (1999). The significance of market capitalization in portfolio management over time. The Journal of Portfolio Management, 25(4), 39-50.

https://doi.org/10.3905/jpm.1999.319750

Roll, R., \& Ross, S. A. (1980). An empirical investigation of the arbitrage pricing theory. The Journal of Finance, 35(5), 1073-1103. https://doi.org/10.1111/j.1540-6261.1980.tb02197.x

Saleem, F., Zafar, L., \& Rafique, B. (2013). Long run relationship between inflation and stock return: evidence from Pakistan. Academic Research International, 4 (2), 407. http://www.savap.org.pk/journals/ARInt./Vol.4(2)/2013(4.2-42).pdf

Sari, R., Soytas, U., \& Hacihasanoglu, E. (2011). Do global risk perceptions influence world oil prices?. Energy Economics, 33(3), 515-524. https://doi.org/10.1016/j.eneco.2010.12.006

Sarwar, G., \& Khan, W. (2017). The effect of US stock market uncertainty on emerging market returns. Emerging Markets Finance and Trade, 53(8), 1796-1811.

https://doi.org/10.1080/1540496X.2016.1180592

Scharfstein, D. S., \& Stein, J. C. (1990). Herd behavior and investment. American Economic Review, 80, 465-479. [Online] Available: https://www.jstor.org/stable/2006678

Scotti, C. (2016). Surprise and uncertainty indexes: Real-time aggregation of real-activity macro-surprises. Journal of Monetary Economics, 82, 1-19.

https://doi.org/10.1016/j.jmoneco.2016.06.002

Shiblee, L. S. (2009). The impact of inflation, GDP, unemployment, and money supply on stock prices. GDP, Unemployment, and Money Supply On Stock Prices (December 29, 2009). 
https://dx.doi.org/10.2139/ssrn.1529254

Shiller, R. J., \& Pound, J. (1989). Survey evidence of dissusing interest among institutional investors. Journal of Economic Behavior and Organization, 12, 47-66.

https://doi.org/10.1016/0167-2681(89)90076-0

Welch, I. (1992). Sequential sales, learning and cascades. Journal of Finance, 47, 695-732. https://doi.org/10.1111/j.1540-6261.1992.tb04406.x

World Federation of Exchanges database.

Xiong, X., Bian, Y., \& Shen, D. (2018). The time-varying correlation between policy uncertainty and stock returns: Evidence from China. Physica A: Statistical Mechanics and its Applications, 499, 413-419. https://doi.org/10.1016/j.physa.2018.02.034

\section{Copyright Disclaimer}

Copyright for this article is retained by the author(s), with first publication rights granted to the journal.

This is an open-access article distributed under the terms and conditions of the Creative Commons Attribution license (http://creativecommons.org/licenses/by/4.0/). 